\title{
An Alkyne Hydrosilylation-Oxidation Strategy for the Selective Installation of Oxygen Functionality
}

\author{
Barry M. Trost ${ }^{\star}$, Zachary T. Ball, and Kai M. Laemmerhold \\ Department of Chemistry, Stanford University, Stanford, CA 94305-5080
}

\begin{abstract}
Alkynes bearing propargylic, homopropargylic, and bis-homopropargylic hydroxyl groups are shown to serve as precursors for ketone or $\alpha$-hydroxy ketone functionality. The approach hinges on the intermediacy of vinylsilanes created through regioselective hydrosilylation catalyzed by the complex $\left[\mathrm{Cp} * \mathrm{Ru}(\mathrm{MeCN})_{3}\right] \mathrm{PF}_{6}$. Several oxidative pathways of linear and cyclic vinylsilanes are studied, and the possibility of diastereoselective epoxidation of cyclic vinylsilanes is demonstrated. The sequences constitute the equivalent of stereoselective aldol, homo-aldol, and bishomo-aldol type processes. The method is applied to a short synthesis of the piperidine alkaloid, spectaline.
\end{abstract}

\section{Introduction}

The controlled introduction of heteroatom functional groups is part and parcel of complex molecule synthesis. Introduction of oxygenation at the ketone or hydroxyl oxidation state from hydrocarbon "feedstock" alkanes, alkenes, and alkynes is a useful way to introduce complex functionality. The use of $\mathrm{C}-\mathrm{C}$ unsaturation for the installation of oxygenation can reduce the reliance on protecting-group manipulation, thereby improving synthetic efficiency. The selective oxygenation of alkenes-processes such as dihydroxylation, hydration (typically as hydroboration-oxidation), and Wacker-type oxidation-is a successful and pervasive method; the development of alkyne oxygenation strategies, on the other hand, lags far behind, despite the potential for increased flexibility and the potential to access different oxidation states at either alkyne carbon.

In principle, alkynes could serve as the basis for the selective syntheses of 1,2-diols, 1,2dicarbonyl compounds, or $\alpha$-hydroxy carbonyl compounds, in addition to the simple ketone or aldehyde hydration products (Scheme 1). This flexibility makes alkynes attractive building blocks, and terminal alkynes have been used to afford carbonyl products available by direct hydration ${ }^{1}$ or through the intermediacy of vinylmetal species. In contrast, the selective introduction on oxygenation to internal alkynes is not well developed. ${ }^{2}$ Hydroboration can be used to provide ketones after oxidation with good control of regiochemistry based on steric differentiation, ${ }^{2}$ and recently the direct hydration of propargylic alcohols has been demonstrated with a gold catalyst. ${ }^{3}$ In addition, intramolecular diol-alkyne bis-cyclization catalyzed by palladium can be used in the selective synthesis of spiroketals. ${ }^{4}$ Despite these achievements, the use of alkynes as substrates for oxygenation in the context of functionalized molecules remains underutilized. Of additional synthetic benefit, alkyne oxygenation methods may well be orthogonal to known olefin oxidation pathways, allowing multiple oxygencontaining functional groups to be incorporated at a late stage in a controlled manner for facile synthetic design. 
Recently, we disclosed preliminary reports of regio- and stereoselective hydrosilylation of internal alkynes—catalyzed by the ruthenium complex $\left[\mathrm{Cp} * \mathrm{Ru}(\mathrm{MeCN})_{3}\right] \mathrm{PF}_{6}(\mathbf{1})-$ providing unique vinylsilanes previously available only by circuitous means (Scheme 2) ${ }^{5-8}$ Of special interest to this work, propargylic, ${ }^{7}$ homopropargylic, ${ }^{5}$ and bishomopropargylic ${ }^{5}$ alcohols all allow selective access to the $(E)$-vinylsilane with distal regioselectivity relative to the hydroxyl group by either intramolecular or intermolecular processes, as appropriate (Scheme 2). The wealth of oxidation chemistry available from vinylsilane intermediates led us to consider the use of alkyne hydrosilylation together with vinylsilane oxidation ${ }^{9-12}$ to introduce functionality distal to a hydroxyl group, which could control regio- and stereochemistry. ${ }^{7}$ In this paper, we provide a full account of these regioselective hydrosilylations and the use of these adducts as an equivalent of an aldol, homo-aldol, and bishomo-aldol process.

BDMS = benzyldimethylsilyl. TDMS = 1,1,3,3-tetramethyldisilazane $\left.\left[\left(\mathrm{HMe}_{2} \mathrm{Si}\right)_{2} \mathrm{NH}\right)\right]$.

\section{Propargylic alcohols}

Propargylic alcohols are surrogates for $\beta$-hydroxy ketones provided that a chemo- and regioselective introduction of a carbonyl group at the alkyne carbon $\beta$ to the alcohol can be performed. Homopropargylic alcohols have been previously utilized for such a purpose via a platinum-catalyzed intramolecular hydrosilylation of homopropargylic alkynes for the selective introduction of a carbonyl group. ${ }^{9,11}$ The asymmetric access to propargylic alcohols, most notably by enantioselective hydrogenation of a ketone ${ }^{13}$ or addition of a zinc acetylide to an aldehyde, ${ }^{14}$ makes this approach attractive. Although the direct hydration of a propargylic alcohol is a potentially attractive solution, obtaining regioselectivity has proven difficult, ${ }^{3}$ and elimination of the hydroxy ketone product under generally acidic hydration conditions is a concern.

At the onset of our work, the regioselective functionalization of propargylic alcohols by hydrosilylation in a general sense was a challenging problem. ${ }^{15}$ We demonstrated efficient intermolecular hydrosilylation with reasonable regio- and stereoselectivity of a variety of propargylic alcohols catalyzed by complex $\mathbf{1}$, providing the ( $Z$ - $-\beta$-vinylsilane as the major product. ${ }^{7}$ Recently, a regiocomplementary process has been demonstrated using an extended linker for intramolecular hydrosilylation of 3-octyn-1-ol. ${ }^{16}$

We chose to pursue selective incorporation of a vinyl C-Si bond to serve as a versatile ketone precursor. Implicit in the approach is a need for a silane oxidation under conditions mild enough to prevent $\beta$-hydroxy elimination and destruction of sensitive functionality. The most obvious silane targets, then, are alkoxy silanes. Although these do function in the hydrosilylation reaction, the selectivity and product stability are compromised with propargylic alcohol substrates (Scheme 2, 9- $\boldsymbol{\beta}$ and $\mathbf{9 - \alpha}$ ). These problems were both solved upon moving to a trialkylsilane reagent (i.e. formation of $\mathbf{1 0}$ ). However trialkylsilanes are not readily oxidized. Dimethylphenylsilyl is the most studied silyl group for use where robust stability is required, 17 but oxidation of the dimethylphenylsilyl group can be incompatible with sensitive functionality, especially acid-sensitive groups. Our search for a balance between stability and ease of oxidation led us to employ benzyldimethylsilane (BDMS-H), an especially attractive silane useful in a number of contexts. 67,18 We have retained a BDMS group through multiple synthetic operations, including those involving organolithium reagents, aqueous acid and base, buffered fluoride necessary for silyl ether deprotection, and strong hydride reductants (i.e. Red$\mathrm{Al})$. Activation of the BDMS group occurs through loss of toluene and formation of a silyl fluoride or silanol species upon treatment with unbuffered TBAF. Typically addition of 1 eq. of TBAF produces complete conversion in $5 \mathrm{~min}$ at $0{ }^{\circ} \mathrm{C}$ in THF or DMF. Subsequent addition of oxidant (aq. $\mathrm{H}_{2} \mathrm{O}_{2}$, urea-hydrogen peroxide adduct, or $m$-CPBA) furnishes the oxidized product. Generally, use of $\mathrm{KHCO}_{3}$ and $\mathrm{H}_{2} \mathrm{O}_{2}$ in methanol was preferred. ${ }^{18,19}$ As shown in 
Scheme 4, the compatibility of the conditions for debenzylation and Tamao-Fleming oxidation with hydrosilylation allows the process to be performed as a one pot operation. While the proposed intermediates $\mathbf{1 2}$ and $\mathbf{1 3}$ have not been isolated, their involvement seems probable. It is interesting to note that no dehydration products are observed in this sequnce. The involvement of a cyclic silylene $\mathbf{1 3}$ wherein such an elimination is geometrically disfavored may account for this behavior. In earlier work using other catalysts to effect intramolecular hydrosilylation of homopropargylic alcohols followed by oxidation to form $\beta$-hydroxy ketones, elimination from the initial enol is not possible. ${ }^{9}$

An additional advantage of this methodology is the ability to further elaborate the vinylsilane 11 prior to unmasking the ketone. As aldol adducts are prone to further reactions such as eliminations, further substitution at the $\alpha$-carbon becomes difficult. ${ }^{20}$ Therefore, an important feature of this approach is the ability to introduce additional complexity at the $\alpha$-carbon. For example, epoxidation occurs with complete diastereoselectivity with $m$-CPBA to provide hydroxy epoxide 15. Others demonstrated the importance of the silyl substituent for good diastereoselectivity. ${ }^{21}$ Thus, as shown in eq. 1, path a, this sequence serves as an efficient route to the epoxy alcohols $\mathbf{1 6}$ diastereoselectively. On the other hand, treatment of $\mathbf{1 5}$ with 1 eq. of TBAF in THF followed by the standard Tamao-Fleming oxidation ${ }^{10}$ provides the $s y n$ diol 17 (eq. 1, path b). The amount of TBAF in the initial stage of the oxidative cleavage is crucial since significant protodesilylation occurs if excess is employed. Purification of the epoxide prior to the Tamao-Fleming oxidation minimized this issue. In this way, the added alkyne unit functions as a hydroxymethyl ketone equivalent with the hydroxy and ketone groups being unmasked simultaneously.
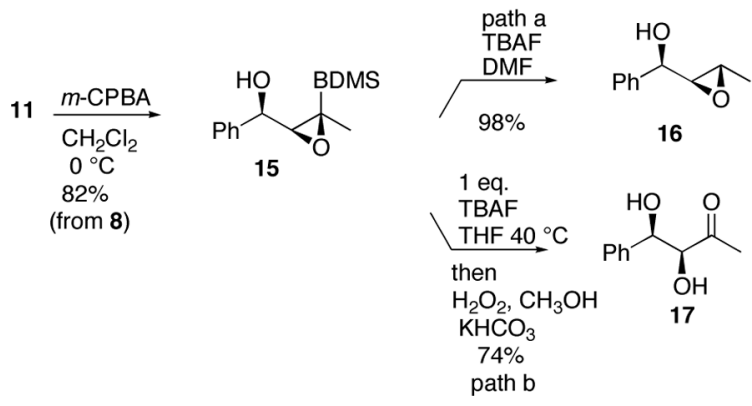

For this aldol surrogate process, the stereochemistry of the $\beta$-hydroxy group derives from the acetylide addition. To the extent that can be controlled in terms of both relative and absolute stereochemistry, the utility of this process is much enhanced. We were interested in finding methods to allow both Felkin-Ahn and chelate-controlled alkyne addition and hence aldol adducts. Diastereoselective addition of acetylide anions to aldehydes has been a challenging problem due to their small size and high reactivity. ${ }^{22}$ The Felkin-Ahn process has been achieved using a tris-alkoxytitanium acetylide, which presumably acts as a very stericallydemanding nucleophile which is coordinatively saturated and thus leaves open no possibility for chelation. ${ }^{23}$ Indeed addition of a titanium acetylide complex converts aldehyde 18 into the anti adduct 19 with a diastereomeric ratio of 9:1 (eq. 2). Chelation control, on the other hand, has been achieved with an alkynylzinc species. ${ }^{24}$ Employing the published conditions, we were able to demonstrate that chelation-controlled addition to the $\alpha$-alkoxy aldehyde $\mathbf{2 1}$ using zinc bromide provides the syn adduct 22 (10:1 d.r.) (eq.3). In both cases, one-pot hydrosilylation followed by oxidation unmasks the aldol adducts. The final $\beta$-hydroxy ketones $\mathbf{2 0}$ and $\mathbf{2 3}$ are isolated as single diastereomers. 

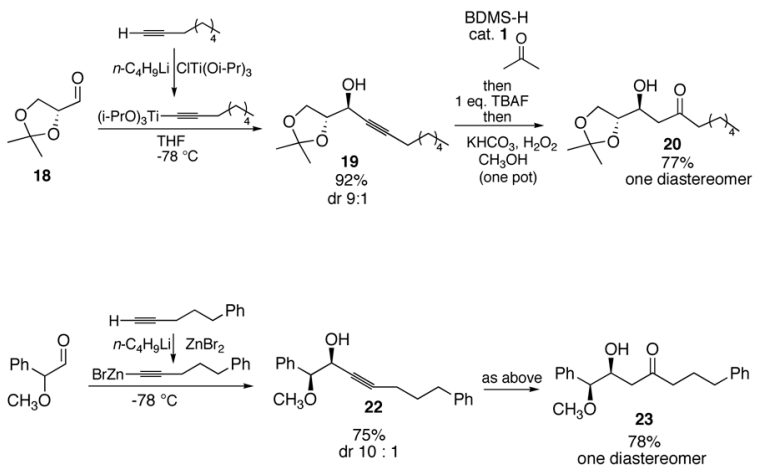

As previously, the intermediate vinyl silane $\mathbf{2 4}$ undergoes clean diastereoselective epoxidation (eq. 4 ) and the resultant silylated epoxide $\mathbf{2 5}$ provides the epoxy alcohol $\mathbf{2 6}$ as a single diastereomer (path a). Alternatively, oxidative cleavage of the silyl group provides diol 27 (path b). Since the ketone $\mathbf{2 7}$ can undergo diastereoselective reduction, the initial stereogenic center then propagates into three more.

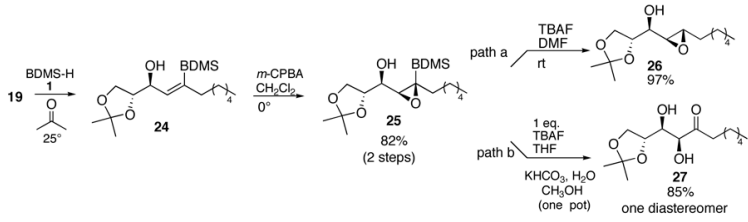

An asymmetric aldol surrogate requires an enantioselective addition of a terminal alkyne to aldehydes or ketones. Following the Carreira protocol ${ }^{14}$ with (+)-N-methylephedrine, cyclohexanecarboxyaldehyde was converted to the propargyl alcohol $\mathbf{2 8}$ in good ee ( $85 \%$ ee) (eq. 5). The one pot hydrosilylation oxidative cleavage then gives the "aldol" product 29 of the same ee. Providing this system via an asymmetric aldol addition of 5-phenyl-2-pentanone would not be trivial considering regio- and enantioselectivity issues. Scheme 5 illustrates a similar sequence from isobutyraldehyde $\mathbf{3 0}$ with a more functionalized acetylene. An improved enantioselectivity in forming adduct $\mathbf{3 1}$ is obtained in this case under identical conditions. Thus, an excellent overall yield of the aldol type product $\mathbf{3 3}$ of $94 \%$ ee is available in a two pot operation from isobutyraldehyde. On the other hand, the intermediate vinylsilane $\mathbf{3 2}$ may be diastereoselectively oxidized to epoxide 34. Derivatizing the free alcohol to the MOM ether 35 prior to unmasking the $\alpha$-hydroxyketone provides the diol product 36 with the two alcohols chemodifferentiated.

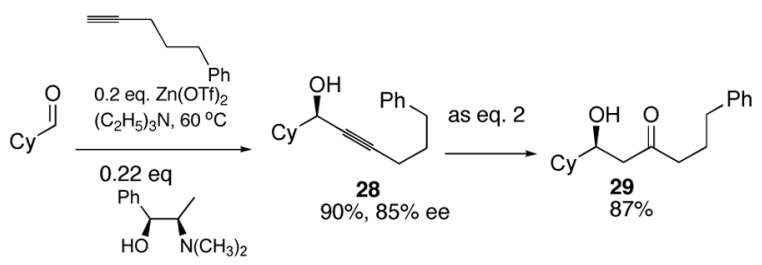

\section{Homo- and bishomopropargylic alcohol substrates}

We were also interested in developing alkyne nucleophiles as methyl ketone enolate or hydroxymethyl ketone enolate equivalents in homoaldol processes, where traditional aldol 
processes are not successful. Homoaldol products could be targeted through formation of either the $\beta \gamma \mathrm{C}-\mathrm{C}$ bond (e.g. a homoenolate-aldehyde coupling) or of the $\alpha, \beta$ bond (e.g. an enolateepoxide coupling). Several examples of the first, $\beta, \gamma$ approach using homoenolate equivalents have been demonstrated, and some recent methods indicate that homoenolates may be important synthetic methods for some target classes. ${ }^{25}$ Formation of the $\alpha, \beta$ bond, however, has few effective solutions, since enolate nucleophiles are typically very poor partners with the requisite epoxide electrophiles. Extending the method of the previous section to view terminal alkynes as functional equivalents of methylketone enolates allows access to a method for the synthesis of the $\alpha, \beta$ bond since alkynyl anions are good nucleophiles for epoxideopening reactions.

The homoaldol process requires a $\gamma$-silyl homoallylic alcohol. The cyclic siloxane derivative of such compounds is readily constructed through an intramolecular hydrosilylation reaction with the same catalyst $\mathbf{1}$ as we previously disclosed (Scheme 6, i) ${ }^{5}$

An example of such a process using an alkyne as a methyl ketone enolate equivalent is shown in Scheme 7. Opening the epoxide $\mathbf{3 7}$ with an alkynyllithium occurs cleanly to generate diastereospecifically the homopropargylic alcohol $\mathbf{3 8}$. A regioselective endo-dig hydrosilylation affords cyclic siloxane 39. At this stage, we encountered some difficulty in performing a silane oxidation. Traditional conditions (aq. $\mathrm{H}_{2} \mathrm{O}_{2}, \mathrm{KF}, \mathrm{KHCO}_{3}, \mathrm{THF} / \mathrm{MeOH}$ ) provided no turnover even at elevated temperatures $\left(50{ }^{\circ} \mathrm{C}\right)$. Switching the solvent to DMF and heating to $80^{\circ} \mathrm{C}$ resulted in decomposition, as did the basic conditions developed by Woerpel. However, we found that a little-used protocol utilizing acidic conditions by introduction of acetic anhydride served to furnish the desired hydroxyl ketone, isolated after conversion to the acetate. ${ }^{26}$ The reasons for the difficulty in obtaining clean oxidation are not obvious for this substrate, though the increased stability of the 6-membered ring silacycle relative to acyclic or 5-membered substrates-together with the steric interactions from the significant substitution about the silacycle-may play an important role.

In an effort to introduce further molecular complexity to cyclic vinylsilane intermediates such as 39, we examined epoxidation, which would allow either protodesilylation to synthesize remote trans-epoxides with control of stereochemistry or silane oxidation to furnish the hydroxyl ketone functionality. The treatment of silane $\mathbf{3 9}$ with $m$-CPBA resulted in clean conversion to a single epoxide product, as judged by ${ }^{1} \mathrm{H}$ NMR analysis of the crude reaction mixture. However, the epoxide was not stable to silica gel, and was isolated in only $31 \%$ yield after chromatography. Analysis of ${ }^{1} \mathrm{H}$ NMR coupling constants or nOe spectra was not instructive, and the relative stereochemistry of epoxide $\mathbf{4 1}$ is based solely on conformational speculation and analogy to later examples.

Encouraged by the apparent opportunity for diastereoselective epoxidation of vinyl silacycles, where no hydroxyl directing group is present, we examined alcohol $\mathbf{4 3}$, readily available by addition of an alkynylaluminum reagent to benzyl glycidyl ether (Scheme 8). Hydrosilylation produced the vinylsilane, which could be oxidized to the epoxide 45 . The use of $m$-CPBA gave the desired epoxide in reasonable diastereoselectivity (4:1). The stereoselectivity of the nondirected epoxidation of cyclic olefins has not been good; silacycles, which possess significantly more conformational freedom than their carbocycle counterparts, might have been expected to be even worse. Interestingly, the use of dimethyldioxirane 27 (DMDO) at low temperatures resulted in a significant increase in selectivity (10:1). ${ }^{28}$ At this stage, we set about finding a method for vinylsilane oxidation to reveal the dihydroxy ketone. The epoxide substrate $\mathbf{4 5}$ was significantly more unstable than the vinylsilane $\mathbf{4 1}$ (see Scheme 7), and we initially were plagued by low mass recovery. Sensing that control of the amount of TBAF might be the source of the problem, a solution was found employing a protocol of slow addition (ca. $4 \mathrm{~h}$ ) of TBAF to a pre-mixed suspension of anhydrous hydrogen peroxide-urea adduct 
(UHP) in a THF solution of the epoxy-silane. ${ }^{29}$ We originally developed this protocol for oxidation of the benzyldimethylsilyl group where protodesilylation competes with oxidation at high fluoride concentration. It may well be that creating the pentavalent silicon fluoride is crucial to maintaining an open coordination site for peroxide. Decomposition pathways such as protodesilylation may result from the coordinatively saturated hexavalent silicon difluoride in the presence of significant quantities of TBAF. The protocol has proven useful for diverse reactions including those for which the original rationale does not necessarily apply.

Employing those conditions to the problem at hand allowed complete conversion without the extensive decomposition observed when the TBAF is introduced dropwise over just several minutes. The $\alpha, \gamma$-dihydroxy ketone was isolated in diastereomerically pure form after protection of the hydroxyl groups as the bis-triethylsilyl ether (46).

The relative stereochemistry of ketone $\mathbf{4 6}$ was established through conversion to the acetonide 48 by the sequence summarized in Scheme 9 . The acetonide ${ }^{13} \mathrm{C}$ NMR shifts establish a 1,3syn arrangement $\left({ }^{13} \mathrm{C}\right.$ NMR acetal ca. $98.9 \mathrm{ppm}$, methyl groups $\left.\Delta>9 \mathrm{ppm}\right)$ rather than a 1,3anti arrangement $\left({ }^{13} \mathrm{C}\right.$ NMR acetal ca. $100.6 \mathrm{ppm}$, methyl groups $\left.\Delta<5 \mathrm{ppm}\right) .{ }^{30}$

Since we anticipated that $\alpha$-face attack would lead to significant torsional strain in the transition state (44 model A, projection down C-Si bond, below), obtention of the product derived from an $\alpha$-face attack of the oxidant on the vinylsilane $\mathbf{4 4}$ was somewhat surprising. The difference between our expecation and experimental observation may be that the longer Si-C bonds remove torsional strain as a significant factor, and the observed product derives from steric screening of the top face (44 model b).

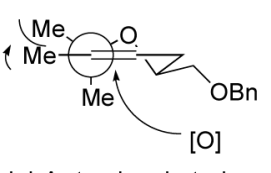

44 model $A$ : torsional strain

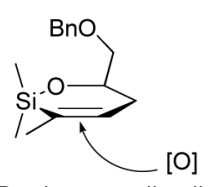

44 model B: planar cyclic siloxane

Homopropargylic alcohol $\mathbf{5 0}$ behaved similarly, producing ketal $\mathbf{5 4}$ by a similar route (Scheme 10). In this instance, treatment of the crude keto-diol $\mathbf{5 3}$ with acidic methanol served to form a single ketal product for characterization purposes. Ketalization also has the effect of differentiating the two hydroxyl functionalities for further synthetic operations. The relative stereochemistry of the 1,3-diol $\mathbf{5 4}$ is assumed by analogy to the previous example (see Scheme 8 and Scheme 9). The stereochemistry at the ketal carbon is assumed to follow from the anomeric effect.

Oxidation problems arose in the context of a more highly-substituted system (Scheme 11). A homopropargylic alcohol $\mathbf{5 6}$ with a 1,2-syn stereochemical relationship was synthesized by coupling of a propargylic mesylate with isobutyraldehyde using in situ formation of an organozinc compound catalyzed by $\operatorname{Pd}(\mathrm{O})$. Though we employed racemic starting mesylate, it has been shown that enantiomerically pure mesylates do faithfully transmit chirality to the product, allowing access to single enantiomerically pure product alcohols. 9,31

Hydrosilylation and epoxidation proceed without incident to afford an epoxide 58, tentatively assigned the $\beta$-epoxide stereochemistry on the basis of ${ }^{1} \mathrm{H}$ NMR coupling constants (Scheme 11). The epoxide, however, proved much more stable and resistant to oxidation. Screening of a variety of oxidation conditions did not result in the formation of the desired ketone products. In general, no reaction is observed, and decomposition is seen only at elevated temperatures $\left(80{ }^{\circ} \mathrm{C}\right)$. The vastly different reactivity of $\mathbf{4 5}, \mathbf{5 2}$, and $\mathbf{5 8}$ toward silane oxidation is curious.

The use of hydroxyl groups to direct selective formation of $\alpha$-hydroxy ketones from alkyne precursors could prove a valuable means of installing oxygenation functionality with control 
of diastereoselectivity even at more remote centers. With this in mind, we targeted the bishomopropargylic alcohol 61a (Scheme 12). We performed reduction of ketone $\mathbf{6 0}$ as previously reported to allow diastereoselective access to homopropargylic alcohol $\mathbf{6 1}$ after alkyne methylation. The original authors reported 15:1 diastereoselectivity in the ketone reductiondirected by coordination to the pendent alkyne - but we observed variable selectivity (ca. 15:1 to 5:1) favoring the syn alcohol 61a and were unable to determine the source of the variation. Pleasantly, a similar hydrosilylation-epoxidation-silane oxidation pathway performed on the mixture of diastereomeric alcohols afforded the analogous 1,4-diol deriviatives 63. This time the product was best isolated as the bis-silyl ether. We do not observe any evidence of the diastereomeric epoxides by crude ${ }^{1} \mathrm{H}$ NMR analysis of the reaction mixture-a gratifying result given the conformational flexibility of 7-membered rings.

In order to determine the relative stereochemistry of the newly formed stereocenter, acetonide formation of the mixture of $63 \mathrm{a}$ and $\mathbf{6 3 b}$ produced a mixture of two inseparable compounds (ca. 5:1) (Scheme 13). The major product 64 exhibited a strong nOe correlation between the methyl doublet and the proton $\alpha$ to the ketone, establishing the all-syn stereochemistry of 63a. Alternatively, treatment of the crude product from the oxidation of 62a with acidic methanol produced two compounds in similar amounts: a ketal 65, and another unstable ketal which decomposed readily on standing. The hydroxylated $\mathrm{C} 3-\mathrm{H}$ of ketal 65 exhibits coupling constants of 6.7, 3.4, and $3.5 \mathrm{~Hz}$ in its ${ }^{1} \mathrm{H}$ NMR spectrum. These peaks are indicative of an axial orientation of the hydroxyl group. The relative stereochemistry of the other groups can be inferred from a 1,3 nOe correlation between the ketal methoxy group and the benzylic $\mathrm{C}-$ $\mathrm{H}$, requiring an equatorial arrangement of the aryl group. Finally, the small $(3.2 \mathrm{~Hz})$ coupling present for the benzylic peak requires axial arrangement of the neighboring methyl group; this must be the case since syn-1,2 stereochemistry was established in the starting material $\mathbf{8 1} .{ }^{32}$

The observed product derives from $\beta$-face attack of the oxidant on the convex face, as depicted in Figure 1. Molecular dynamics calculations indicate that the preferred conformation is the pseudo-boat form as shown. (Figure 1).

\section{A synthesis of (+)-spectaline using a vinylsilane-based homoaldol equivalent}

Spectaline is a member of a class of all-cis 2,6-disubstituted, 3-hydroxy piperidine alkaloids that includes carpamic acid, azimic acid, cassine, and prosafrinine. Hydroxylated piperidine alkaloids can possess important biological activity, stemming from their abilities as carbohydrate mimics in the context of enzyme inhibition. 33 These compounds have been the targets of numerous synthetic efforts. ${ }^{34}$ However, extant syntheses are plagued by protecting group manipulations and functional group interconversions leading to synthetic inefficiency. Reductive amination of an amino-ketone has been shown to be a diastereoselective and efficient strategy for the synthesis of 3-hydroxy piperidine alkaloids, and such a retrosynthetic disconnection in this case furnishes the $\delta$-amino, $\gamma$-hydroxyketone $\mathbf{6 8}$. The ease of forming such $\gamma$-hydroxyketone "homoaldol" products by the method described here interested us in the use of intramolecular hydrosilylation for the selective installation of ketone functionality. This approach to the spectaline alkaloids allows simultaneous late-stage elaboration of ketone and hydroxyl functionality. By installing the amine functionality as an azide group, this overall strategy avoids use of any protecting groups for the synthesis of the piperidine core (Scheme 14). The atom-economical approach employs only dimethylsiloxane and dinitrogen as wasted atoms in the synthesis of the central core and allows a short step count as well.

In the synthetic direction, straightforward processes furnish alkyne $\mathbf{7 3}$ (Scheme 15). Starting from the known epoxide 75-available by resolution of ( \pm )-1-buten-3-ol (74) through catalytic asymmetric epoxidation ${ }^{35}$ _followed by Mitsunobu displacement with $\mathrm{Zn}\left(\mathrm{N}_{3}\right)_{2} \cdot 2 \mathrm{pyr}^{36}$ gave a volatile azido-expoxide. Although we could isolate the azido-epoxide in low yield, it was far 
more convenient and efficient to treat the crude azido-epoxide with the alkynyllithium generated from terminal alkyne $\mathbf{7 3}$ to furnish the epoxide-opening product $\mathbf{7 6}$.

The azido-alcohol 76 sets the stage for a key regioselective ketone introduction at the distal position of the alkyne. Intramolecular hydrosilylation proceeds well to furnish the product cyclic siloxane in nearly quantitative yield (Scheme 16). The tolerance of the azide functionality in the ruthenium-catalyzed hydrosilylation is demonstrated for the first time with this substrate. The stage is now set for unmasking the ketone. The oxidation of silanes containing azide functionality has been demonstrated for a single substrate 37 so we were encouraged to pursue direct oxidation to the ketone 78. The oxidation was quite slow under typical conditions $\left(\mathrm{H}_{2} \mathrm{O}_{2}, \mathrm{KF}, \mathrm{KHCO}_{3}, \mathrm{MeOH} / \mathrm{THF}\right.$ at rt provided $38 \%$ conversion over $\left.6 \mathrm{~d}\right)$. Unfortunately, raising the temperature or switching to more active oxidation conditions (TBAF, $\mathrm{H}_{2} \mathrm{O}_{2}$, DMF) resulted in significant decomposition. We also pursued initial azide reduction prior to silane oxidation. Treatment of the azide $\mathbf{7 8}$ with triphenylphosphine or trimethylphosphine allowed clean conversion to an intermediate iminophosphorane. Unfortunately, we had difficulty hydrolyzing the intermediate iminophosphorane in the presence of the rather sensitive cyclic siloxane, and product characterization became troublesome. As a result of these difficulties and the step economy of performing the oxidation in the presence of the azide, we re-examined the oxidation. Again we found that dropwise addition of TBAF over $4 \mathrm{~h}$ to a mixture of vinylsilane and oxidant provided the solution. In this case, dropwise addition in THF resulted in a clean reaction, but did not significantly improve the reaction rate. However, switching the solvent to DMF inproved the reaction rate and allowed complete conversion without the extensive decomposition observed when all the TBAF is introduced within 5 min.

It thus remained only to perform the reductive amination and remove the distal ketal protecting group to complete the synthesis. Fortunately, treatment of the azido-ketone with $\mathrm{Pd} / \mathrm{C}$ under a pressure of $\mathrm{H}_{2}(60 \mathrm{psi})$ served in one step to reduce the azide - revealing the amine functionality - and to bring about imine formation and reduction to the desired piperidine target (Scheme 16). ${ }^{38}$ Treatment of the crude mixture with aq. $\mathrm{HCl}$ removed the ketal functionality to allow isolation of the (+)-spectaline target. Of note, our endo-dig hydrosilylation-oxidation strategy allows for a convergent strategy and avoids the need for any traditional protecting groups in the piperidine core and only one protecting group for the side chain. The net result is a synthesis having a longest linear sequence of 9 steps (11 total steps) and proceeding in $>18 \%$ yield.

\section{Conclusions}

Strategically, the availability of the ruthenium-catalyzed regioselective hydrosilylation provides the very useful $\beta-, \gamma-$, and $\delta$-hydroxyketones as illustrated in Scheme 17 . The complementary behavior of rhodium, platinum, or palladium-catalyzed hydrosilylation compared to ruthenium translates into regiocomplementary products as summarized in Scheme 18. The masking of the ketone or $\alpha$-hydroxyketone in the form of the vinylsilane has the additional advantage of serving as a chemically unreactive form. Furthermore, the prospect of introducing substituents other than hydroxyl by electrophilic additions to the vinylsilane offer the promise of further broadening of the scope of this strategy.

Here we present a strategy for the introduction of regio- and stereodefined oxygen functionality from internal alkyne building blocks though vinylsilane intermediates. In addition to discriminating between the two termini of the alkyne, the silyl intermediate serves as a diastereocontrol element, allowing even quite remote stereocontrol of olefin functionalization by enforcing $\mathrm{A}^{1,3}$ strain with allylic alcohols or through cyclic intermediates with homo- and bishomopropargylic alcohols. The use of such cyclic vinylsilane intermediates may well provide a means of achieving remote stereocontrol in olefin addition reactions in general. 


\section{Experimental Section}

\section{(2R,3S)-4-undecyn-1,2,3-triol 1,2-isopropylidene ketal, 19}

This procedure was adapted from the method of Shimizu. ${ }^{7}$ A solution of 1-octyne $(1.59 \mathrm{~mL}$, $10.8 \mathrm{mmol})$ in THF $(10 \mathrm{~mL})$ under $\mathrm{Ar}$ at $-78{ }^{\circ} \mathrm{C}$ was treated with butyllithium $(1.59 \mathrm{~mL}, 10.8$ mmol, $1.48 \mathrm{M}$ in hexanes) dropwise. After $30 \mathrm{~min}, \mathrm{ClTi}(\mathrm{O} i-\mathrm{Pr})_{3}(2.57 \mathrm{~mL}, 10.8 \mathrm{mmol})$ was added and the flask warmed to $-60^{\circ} \mathrm{C}$. To maintain solubility, additional THF $(20 \mathrm{~mL})$ was added and the solution was stirred for $90 \mathrm{~min}$ prior to re-cooling to $-78^{\circ} \mathrm{C}$. $(R)$-Glyceraldehyde isopropylidene $\operatorname{ketal}^{1}(0.70 \mathrm{~g}, 5.38 \mathrm{mmol})$ was then added via syringe in one portion and the mixture stirred for $2 \mathrm{~h}$ prior to quenching with sat. aq. $\mathrm{NH}_{4} \mathrm{Cl}(20 \mathrm{~mL})$ at $-78{ }^{\circ} \mathrm{C}$. Water $(30$ $\mathrm{mL}$ ) was then added and the reaction extracted with ether $(3 \times 30 \mathrm{~mL})$. The ether extracts were washed with brine $(20 \mathrm{~mL})$ and dried over $\mathrm{MgSO}_{4}$, and the solvents were removed in vacuo. Silica gel chromatography gave $1.19 \mathrm{~g}(92 \%)$ of the desired alcohol as a 9:1 mixture of epimeric diols favoring the trans. ${ }^{1} \mathrm{H}$ NMR spectra of trans and cis components are very similar to a previously reported addition. 8

Data for major isomer- ${ }^{1} \mathrm{H}$ NMR $\left(500 \mathrm{MHz}, \mathrm{CDCl}_{3}\right) \delta 4.48(\mathrm{~m}, 1 \mathrm{H}), 4.21(\mathrm{ddd}, J=6.5$, $6.5,4.0 \mathrm{~Hz}, 1 \mathrm{H}), 4.03-4.08(\mathrm{~m}, 2 \mathrm{H}), 2.26(\mathrm{~d}, J=4.4 \mathrm{~Hz}, 1 \mathrm{H}), 2.20(\mathrm{td}, J=7.2,2.1 \mathrm{~Hz}, 2 \mathrm{H})$, $1.45-1.51(\mathrm{~m}, 2 \mathrm{H}), 1.46(\mathrm{~s}, 3 \mathrm{H}), 1.37(\mathrm{~s}, 3 \mathrm{H}), 1.24-1.36(\mathrm{~m}, 6 \mathrm{H}), 0.88(\mathrm{t}, J=7.0 \mathrm{~Hz}$, $3 \mathrm{H}) .{ }^{13} \mathrm{C}$ NMR $\left(125 \mathrm{MHz}, \mathrm{CDCl}_{3}\right) \mathrm{d} 110.0,87.3,78.1,77.0,65.2,62.4,31.3,28.5,28.4,26.3$, 25.2, 22.5, 18.7, 14.0. IR (thin film) 3452 (br, OH), 2933, 2234 (w), 1372, 1254, 1216, 1153, $1070,851 \mathrm{~cm}^{-1} \cdot[\alpha]^{26}{ }_{\mathrm{D}}+17.8^{\circ}\left(\mathrm{c} 1.0, \mathrm{CHCl}_{3}\right)$. Anal. calc. for $\mathrm{C}_{14} \mathrm{H}_{24} \mathrm{O}_{3}: \mathrm{C}, 69.96 ; \mathrm{H}, 10.07$; Found: C, 69.79; H, 10.15 .

\section{(2R,3S)-1,2,3-trihydroxy-5-undecanone 1,2-isopropylidene ketal, 20}

The alkyne $19(120 \mathrm{mg}, 0.50 \mathrm{mmol})$ and BDMS-H $(104 \mathrm{~mL}, 0.60 \mathrm{mmol})$ in acetone $(1.0 \mathrm{~mL})$ was treated at $0{ }^{\circ} \mathrm{C}$ with complex $1(7.8 \mathrm{mg}, 0.015 \mathrm{mmol})$. the mixture was allowed to warm to rt over $30 \mathrm{~min}$. It was then re-cooled to $0{ }^{\circ} \mathrm{C}$, diluted with THF $(1.5 \mathrm{~mL})$, and TBAF $(0.60$ $\mathrm{mL}, 0.60 \mathrm{mmol}, 1.0 \mathrm{M}$ soln in THF) was added dropwise. After $20 \mathrm{~min}, \mathrm{MeOH}(1.0 \mathrm{~mL})$ was introduced, followed by solid potassium bicarbonate $(150 \mathrm{mg}, 1.5 \mathrm{mmol})$ and aq. $\mathrm{H}_{2} \mathrm{O}_{2} \cdot(0.80$ $\mathrm{mL}, 30 \% \mathrm{soln})$. The mixture was then stirred for $36 \mathrm{~h}$ at rt, at which time it was diluted with water $(10 \mathrm{~mL})$ and extracted with EtOAc $(3 \times 10 \mathrm{~mL})$. The organic extracts were washed with brine $(10 \mathrm{~mL})$, dried over $\mathrm{Na}_{2} \mathrm{SO}_{4}$, and concentrated in vacuo. The residue was purified on a silica gel column (eluent: 85:15:1 pet. ether: EtOAc: $\mathrm{MeOH}$ ) to give $99 \mathrm{mg}(77 \%)$ of the desired ketone as a single isomeric compound.

${ }^{1} \mathrm{H}$ NMR (500 MHz, $\left.\mathrm{CDCl}_{3}\right) \delta 4.08(\mathrm{~m}, 1 \mathrm{H}), 3.92-3.95(\mathrm{~m}, 3 \mathrm{H}), 3.27$ (br OH, 1H), 2.82 (dd, $J=7.5,1.8 \mathrm{~Hz}, 1 \mathrm{H}), 2.57(\mathrm{~m}, 1 \mathrm{H}), 2.45(\mathrm{t}, J=7.5 \mathrm{~Hz}, 2 \mathrm{H}), 1.57(\mathrm{~m}, 2 \mathrm{H}), 1.39(\mathrm{~s}, 3 \mathrm{H}), 1.34$ $(\mathrm{s}, 3 \mathrm{H}), 1.26-1.30(\mathrm{~m}, 6 \mathrm{H}), 0.87(\mathrm{t}, J=7.0 \mathrm{~Hz}, 3 \mathrm{H}) .{ }^{13} \mathrm{C} \mathrm{NMR}\left(125 \mathrm{MHz}, \mathrm{CDCl}_{3}\right) \delta 212.4$, $109.4,77.5,69.1,66.9,45.1,43.7,31.5,28.8,26.7,25.1,23.5,23.5,22.4,14.0$. IR (thin film)

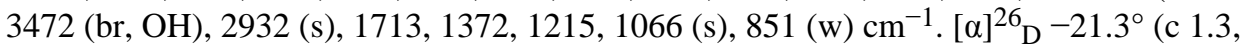
$\mathrm{CHCl}_{3}$ ). Anal. calc. for $\mathrm{C}_{14} \mathrm{H}_{26} \mathrm{O}_{4}: \mathrm{C}, 65.09 ; \mathrm{H}, 10.14$; Found: C, 64.84; H, 9.92.

\section{(R)-[(2S,3R)-3-(Benzyldimethylsilyl)-3-hexyl-oxiranyl]-((R)-2,2-dimethyl-[1,3]dioxolan-4-yl)- methanol, 25}

Following the general procedure for the synthesis of $( \pm)-(\mathrm{R})-[(2 \mathrm{~S}, 3 \mathrm{R})-3-$

(benzyldimethylsilyl)-3-methyloxiranyl]-phenylmethanol (15), vinylsilane 24 (205 mg, 0.52 mmol) was treated with $m$-CPBA (260 mg, $1.04 \mathrm{mmol})$ in $\mathrm{CH}_{2} \mathrm{Cl}_{2}(5.0 \mathrm{~mL})$ to give $180 \mathrm{mg}$ $(84 \%)$ of the desired epoxide as a 9:1 mixture of relative epimers at $\mathrm{C} 2$ from the initial alkyne addition. Purification on silica gel (eluent: 20:1 to 10:1 pet. ether: acetone). 
Data for major isomer- ${ }^{1} \mathrm{H}$ NMR $\left(500 \mathrm{MHz}, \mathrm{C}_{6} \mathrm{D}_{6}\right) \delta$ 7.09-7.13 (m, 2H), 6.94-7.00 (m, $3 \mathrm{H}), 4.03(\mathrm{ddd}, J=5.3,5.3,1.6 \mathrm{~Hz}, 1 \mathrm{H}), 3.92-3.99(\mathrm{~m}, 2 \mathrm{H}), 3.62(\mathrm{~m}, 1 \mathrm{H}), 2.96(\mathrm{~d}, J=6.7 \mathrm{~Hz}$, $1 \mathrm{H}), 2.31(\mathrm{~d}, J=13.7 \mathrm{~Hz}, 1 \mathrm{H}), 2.22(\mathrm{~d}, J=13.7 \mathrm{~Hz}, 1 \mathrm{H}), 1.99(\mathrm{~d}, J=4.1 \mathrm{~Hz}, 1 \mathrm{H}), 1.90(\mathrm{~m}$, $1 \mathrm{H}), 1.35(3,3 \mathrm{H}), 1.22(\mathrm{~s}, 3 \mathrm{H}), 1.08-1.26(\mathrm{~m}, 9 \mathrm{H}), 0.84(\mathrm{t}, J=7.1 \mathrm{~Hz}, 3 \mathrm{H}), 0.09(\mathrm{~s}, 3 \mathrm{H}), 0.08$ (s, 3H). ${ }^{13} \mathrm{C}$ NMR $\left(100 \mathrm{MHz}, \mathrm{C}_{6} \mathrm{D}_{6}\right) \delta 139.5,128.8,128.6,124.8,109.6,77.3,71.6,67.6,65.8$, 58.7, 37.8, 32.1, 29.7, 26.8, 25.7, 25.3, 24.8, 23.0, 14.3, -3.0, -3.1. IR (thin film) 3452 (br, $\mathrm{OH}), 2931,1600(\mathrm{w}), 1251,1207,1067,828,700 \mathrm{~cm}^{-1} \cdot[\alpha]^{26} \mathrm{D}+14.3^{\circ}\left(\mathrm{c} 1.0, \mathrm{CH}_{2} \mathrm{Cl}_{2}\right)$. This compound is further characterized after conversion to ketone $\mathbf{3 3}$.

(1S,2S)-1-((R)-2,2-Dimethyl-[1,3]dioxolan-4-yl)-1,2-dihydroxy-nonan-3-one, 27

Following the general procedure for the oxidative desilylation given for 17, employing epoxy silane ( $90.0 \mathrm{mg}, 0.216 \mathrm{mmol}$ ), TBAF ( $0.216 \mathrm{ml}, 0.216 \mathrm{mmol}, 1.0 \mathrm{M}$ in THF), $\mathrm{KHCO}_{3}$ (65 mg, $0.64 \mathrm{mmol})$ and aq. $\mathrm{H}_{2} \mathrm{O}_{2}(0.3 \mathrm{ml}, 30 \%$ soln $)$ in THF $(0.7 \mathrm{~mL})$ and $\mathrm{MeOH}(0.7 \mathrm{~mL})$ provided $51.8 \mathrm{mg}(85 \%)$, of the desired diol, isolated as an inseparable 9:1 mixture of relative epimers at C-2 carried through from the initial alkyne addition. Chromatography eluent: 80:20:1 to 66:33:1 pet. ether: EtOAc: $\mathrm{MeOH}$.

$\mathrm{R}_{\mathrm{f}}$ : 0.37 (67:33:1 pet.ether: EtOAc: methanol). ${ }^{1} \mathrm{H}$ NMR (500 MHz, $\left.\mathrm{CDCl}_{3}\right) \delta 4.41$ (d, $J=2.4$ $\mathrm{Hz}, 1 \mathrm{H}), 4.12-4.15(\mathrm{~m}, 2 \mathrm{H}), 4.07(\mathrm{~m}, 1 \mathrm{H}), 3.89(\mathrm{~m}, 1 \mathrm{H}), 3.78(\mathrm{~d}, J=3.6 \mathrm{~Hz}, 1 \mathrm{H}), 2.48-2.63$ $(\mathrm{m}, 2 \mathrm{H}), 2.10(\mathrm{~d}, \mathrm{~J}=10.4 \mathrm{~Hz}, 1 \mathrm{H}), 1.66(\mathrm{~m}, 2 \mathrm{H}), 1.48(\mathrm{~s}, 3 \mathrm{H}), 1.38(\mathrm{~s}, 3 \mathrm{H}), 1.26-1.35(\mathrm{~m}, 6 \mathrm{H})$, $0.89(\mathrm{t}, J=7.0 \mathrm{~Hz}, 3 \mathrm{H}) .{ }^{13} \mathrm{C} \mathrm{NMR}\left(125 \mathrm{MHz}, \mathrm{CDCl}_{3}\right) \delta 210.4,109.4,76.1,75.6,72.4,66.8$, 37.7, 31.5, 28.8, 27.0, 25.0, 23.4, 22.4, 14.0. IR (thin film) 3445 (br, OH), 2933, 1715, 1372, $1216,1069,847 \mathrm{~cm}^{-1} \cdot[\alpha]^{26}{ }_{D}+51.4^{\circ}\left(\mathrm{c} 1.0, \mathrm{CHCl}_{3}\right)$. Anal. calc. for $\mathrm{C}_{14} \mathrm{H}_{26} \mathrm{O}_{3}: \mathrm{C}, 61.29 ; \mathrm{H}$, 9.55; Found: C, 61.42; H, 9.52.

\section{General procedure for the one-pot hydrosilylation and oxidative desilylation: (S)-1- cyclohexyl-1-hydroxy-6-phenyl-hexan-3-one, 28}

To a solution of $(R)$-1-cyclohexyl-6-phenyl-2-hexyn-1-ol (21) (50 mg, $0.20 \mathrm{mmol}$ ) and BDMS$\mathrm{H}(87.9 \mathrm{mg}, 0.59 \mathrm{mmol})$ in $\mathrm{CH}_{2} \mathrm{Cl}_{2}(0.4 \mathrm{~mL})$ is added complex $1(4.9 \mathrm{mg}, 0.01 \mathrm{mmol})$ at $0^{\circ}$ C. The solution is allowed to warm to rt and stirred for $30 \mathrm{~min}$. The solution is cooled to $0{ }^{\circ} \mathrm{C}$, and THF $(0.7 \mathrm{~mL})$ and TBAF $(0.58 \mathrm{~mL}, 0.58 \mathrm{mmol}, 1.0 \mathrm{M}$ in THF $)$ are added and the solution is stirred for 15 minutes. Aq. $\mathrm{H}_{2} \mathrm{O}_{2}(1.9 \mathrm{~mL}, 10.7 \mathrm{mmol}), \mathrm{MeOH}(0.7 \mathrm{~mL})$ and $\mathrm{KHCO}_{3}(176$ $\mathrm{mg}, 1.76 \mathrm{mmol}$ ) are added to the solution. The solution is then warmed to rt and stirred for 18 h. Brine $(10 \mathrm{~mL})$ is added and the mixture extracted with ether $(2 \times 30 \mathrm{~mL})$. The organic layer is washed with sat. aq. $\mathrm{Na}_{2} \mathrm{~S}_{2} \mathrm{O}_{3}(10 \mathrm{~mL})$ and brine $(10 \mathrm{~mL})$ and dried over $\mathrm{MgSO}_{4}$. Purification on silica gel column (eluent: 8:1 pet. ether: EtOAc) afforded (S)-1-cyclohexyl-1-hydroxy-6phenyl-3-hexanone (46.3 mg, 87\%).

$\mathrm{R}_{\mathrm{f}}$ : 0.57 (4:1 P.E.: EtOAc). ${ }^{1} \mathrm{H}$ NMR (300 MHz, $\left.\mathrm{CDCl}_{3}\right) \delta$ 7.15-7.30 (m, 5H), $3.78(\mathrm{~s}, 1 \mathrm{H})$, 2.95 (s, 1H), 2.42-2.64 (m, 5H), 1.61-1.96 (m, 7H), 0.95-1.43 (m, 7H). ${ }^{13} \mathrm{C}$ NMR (75 MHz, $\left.\mathrm{CDCl}_{3}\right) \delta 212.4,141.4,128.41,128.36,126.0,71.6,46.1,42.9,42.8,34.9,28.8,28.2,26.4$, 26.1, 26.0, 27.9. IR (thin film) 3363 (br), 2915, 2850, 1702 (s), 1446 (w), 1403 (w), 1087 (w), $699 \mathrm{~cm}^{-1}$. Anal. Calc. for $\mathrm{C}_{18} \mathrm{H}_{26} \mathrm{O}_{2}$ : C, 78.79; H, 9.55. Found: C, 79.00; H, 9.45. $[\alpha]^{25}{ }_{\mathrm{D}}+33.9^{\circ}$ (c 1.0 in $\mathrm{CHCl}_{3}$ ). $\mathrm{mp} 65-67^{\circ} \mathrm{C}$.

\section{(R)-Methyl 12-hydroxy-13-methyl-10-tetradecynoate, 31}

Adapted from the method of Carreira. ${ }^{14}$ A flask charged with zinc triflate $(360 \mathrm{mg}, 1.0 \mathrm{mmol})$ was placed under vacuum $(1 \mathrm{mmHg})$ and heated to $125^{\circ} \mathrm{C}$ for $2 \mathrm{hr}$. (+)- $\mathrm{N}$-methylephedrine $(197 \mathrm{mg}, 1.10 \mathrm{mmol})$ was added to the flask, which was placed under an Ar atmosphere. Toluene $(5.0 \mathrm{~mL})$ is added to the flask, and the mixture stirred for $2 \mathrm{hr}$. Methyl 10-undecynoate $(1.18 \mathrm{~g}, 6.0 \mathrm{mmol})$ was added to the flask, and after $15 \mathrm{~min}$, isobutyraldehyde $(454 \mu \mathrm{L}, 5.0$ $\mathrm{mmol}$ ) was added to the flask, which was then heated to $60^{\circ} \mathrm{C}$ and stirred for $12 \mathrm{hr}$. The mixture 
was then quenched by addition of sat. aq. $\mathrm{NH}_{4} \mathrm{Cl}(20 \mathrm{~mL})$ and extracted with ether $(3 \times 15$ $\mathrm{mL}$ ). The extracts were washed with brine $(15 \mathrm{~mL})$, dried over $\mathrm{MgSO}_{4}$, and concentrated under reduced pressure. Purification on silica gel (eluent 80:20:1, then 70:30:1 pet. ether: EtOAc: $\mathrm{MeOH})$ gave the desired alcohol $(1.09 \mathrm{~g}, 81 \%)$ as a colorless oil. The enantiomeric excess was determined to be $94 \%$, presumed to be the $(R)$ stereochemistry by analogy to Careira's published results. For purposes of ee determination, racemic material was generated in acetonitrile using $\mathrm{Zn}(\mathrm{OTf})_{2} .{ }^{14}$

$\mathrm{R}_{\mathrm{f}} 0.43$ (80:20:1 pet. ether: EtOAc: $\left.\mathrm{MeOH}\right) .{ }^{1} \mathrm{H}$ NMR $\left(300 \mathrm{MHz}, \mathrm{CDCl}_{3}\right) \delta 3.66(\mathrm{~s}, 1 \mathrm{H}), 2.30$ $(\mathrm{t}, J=7.4 \mathrm{~Hz}, 2 \mathrm{H}), 2.20(\mathrm{td}, J=6.8,1.6 \mathrm{~Hz}, 2 \mathrm{H}), 1.77-1.87(\mathrm{~m}, 2 \mathrm{H}), 1.61(\mathrm{~m}, 2 \mathrm{H}), 1.48(\mathrm{~m}$, $2 \mathrm{H}), 1.24-1.40(\mathrm{~m}, 8 \mathrm{H}), 0.98(\mathrm{~d}, J=6.1 \mathrm{~Hz}, 3 \mathrm{H}), 0.96(\mathrm{~d}, J=6.1 \mathrm{~Hz}, 3 \mathrm{H}) .{ }^{13} \mathrm{C} \mathrm{NMR}(75 \mathrm{MHz}$, $\left.\mathrm{CDCl}_{3}\right) \mathrm{d}$ 174.3, 86.1 , 79.8, 68.1, 51.4, 34.6, 34.0, 29.04, 28.99, 28.8, 28.6, 24.9, 18.6, 18.1, 17.4. $[\alpha]^{26}{ }_{D}+0.94^{\circ}\left(\mathrm{c} 1.3, \mathrm{CHCl}_{3}\right.$ ). Anal. calc. for $\mathrm{C}_{16} \mathrm{H}_{28} \mathrm{O}_{3}$ : C, 71.60; H, 10.52; Found: $\mathrm{C}$, 71.60; H, 10.34. Enantiomeric excess determined by HPLC [Chiralcel ${ }^{\circledR}$ AS column, eluting with 94:6 heptane/iPrOH, $1 \mathrm{~mL} / \mathrm{min}, 225 \mathrm{~nm}$ : $(R)$-enantiomer $t_{\mathrm{R}} 9.32 \mathrm{~min}$, $(S)$-enantiomer $t_{\mathrm{R}}$ $10.84 \mathrm{~min}]$.

\section{Methyl (S)-12-hydroxy-13-methyl-10-oxo-tetradecanoate, 33}

Following the general procedure for one-pot hydrosilylation and oxidative desilylation given for 28, employing alkyne 31 (134 mg, $0.50 \mathrm{mmol}$ ), BDMS-H (103 mg, $0.60 \mathrm{mmol}$ ), complex $1(5.0 \mathrm{mg}, 0.012 \mathrm{mmol})$ in $\mathrm{CH}_{2} \mathrm{Cl}_{2}(0.5 \mathrm{ml})$ at $-30{ }^{\circ} \mathrm{C}$ and TBAF $(0.60 \mathrm{ml}, 0.60 \mathrm{mmol}, 1.0 \mathrm{M}$ in THF) and $\mathrm{KHCO}_{3}(150 \mathrm{mg}, 1.5 \mathrm{mmol})$ and aq. $\mathrm{H}_{2} \mathrm{O}_{2}(0.6 \mathrm{ml}, 30 \%$ soln $)$ in THF $(1.0 \mathrm{~mL})$ and $\mathrm{MeOH}(1.0 \mathrm{~mL})$ provided the product hydroxyl ketone $(114 \mathrm{mg}, 80 \%)$. Chromatography eluent: 80:20:1 pet. ether: EtOAc: MeOH.

$\mathrm{R}_{\mathrm{f}}$ : 0.31 (80:20:1 pet.ether: EtOAc: methanol). ${ }^{1} \mathrm{H}$ NMR $\left(500 \mathrm{MHz}, \mathrm{CDCl}_{3}\right) \delta 3.83(\mathrm{~m}, 1 \mathrm{H})$, $3.69(\mathrm{~s}, 3 \mathrm{H}), 3.02(\mathrm{br} \mathrm{OH}, 1 \mathrm{H}), 2.60(\mathrm{dd}, J=17.3,2.3 \mathrm{~Hz}, 1 \mathrm{H}), 2.51(\mathrm{dd}, J=17.3,9.8 \mathrm{~Hz}, 1 \mathrm{H})$, $2.46(\mathrm{t}, J=7.5 \mathrm{~Hz}, 2 \mathrm{H}), 2.32(\mathrm{t}, J=7.5 \mathrm{~Hz}, 2 \mathrm{H}), 1.57-1.73(\mathrm{~m}, 5 \mathrm{H}), 1.27-1.33(\mathrm{~m}, 8 \mathrm{H}), 0.96$ $(\mathrm{d}, J=6.7 \mathrm{~Hz}, 3 \mathrm{H}), 0.93(\mathrm{~d}, J=6.8 \mathrm{~Hz}, 3 \mathrm{H}) .{ }^{13} \mathrm{C} \mathrm{NMR}\left(125 \mathrm{MHz}, \mathrm{CDCl}_{3}\right) \delta 212.9,174.3$, $72.3,51.5,45.9,43.7,34.0,33.0,29.1,29.03,29.02,24.9,23.5,18.3,17.8$. IR (thin film) 3526 (br, OH), 2931 (s), 2857, 1740 (s), 1711, 1438, 1368, $1173 \mathrm{~cm}^{-1} \cdot[\alpha]^{26}{ }_{\mathrm{D}}-24.7^{\circ}$ (c 1.0, $\mathrm{CHCl}_{3}$ ). Anal. Calc. for $\mathrm{C}_{16} \mathrm{H}_{30} \mathrm{O}_{4}: \mathrm{C}, 67.10 ; \mathrm{H}, 10.56$. Found: C, 66.94; H, 10.35. HRMS$\mathrm{EI}(\mathrm{m} / \mathrm{z})$ : $[\mathrm{M}-\mathrm{OH}]^{+}$calcd for $\mathrm{C}_{16} \mathrm{H}_{29} \mathrm{O}_{3}: 269.2117$; found: 269.2127 .

\section{General Procedure for intramolecular hydrosilylation. ( \pm )-6-Benzyloxymethyl-2,2,3- trimethyl-5,6-dihydro-2H-[1,2]oxasiline, 44}

A round-bottomed flask was charged with 1-benzyloxy-hex-4-yn-2-ol (43) (300 mg, 1.469 $\mathrm{mmol})$ under Ar at rt. To the neat alcohol was added 1,1,3,3-tetramethyldisilazane (1.3 mL, $7.344 \mathrm{mmol}$ ) and the flask heated to $50{ }^{\circ} \mathrm{C}$ for $2 \mathrm{~h}$. Next, the flask was cooled to ambient temperature and placed under vacuum (ca. $1 \mathrm{mmHg}$ ) for $45 \mathrm{~min}$ to remove the volatile species. $\mathrm{An} \mathrm{Ar}$ atmosphere was then re-introduced and the residue taken up in $\mathrm{CH}_{2} \mathrm{Cl}_{2}(3.6 \mathrm{~mL})$. The flask was cooled to $0{ }^{\circ} \mathrm{C}$ and solid $\left[\mathrm{Cp} * \mathrm{Ru}(\mathrm{MeCN})_{3}\right] \mathrm{PF}_{6}(14.8 \mathrm{mg}, 0.029 \mathrm{mmol})$ was added to the solution. The flask was allowed to warm to rt, and after $2 \mathrm{~h}$, the solution was diluted with ether $(15 \mathrm{~mL})$ and filtered through a short plug of florisil, washing with additional ether (20 $\mathrm{mL}$ ). After concentration under reduced pressure the cyclic siloxane was obtained as a colorless oil (347 mg, $90 \%)$.

$\mathrm{R}_{\mathrm{f}}: 0.48$ (10:1 pet. ether: EtOAc). ${ }^{1} \mathrm{H}$ NMR $\left(400 \mathrm{MHz}, \mathrm{C}_{6} \mathrm{D}_{6}\right) \delta 7.06-7.29(\mathrm{~m}, 5 \mathrm{H}), 6.25(\mathrm{~m}$, $1 \mathrm{H}), 4.38(\mathrm{~d}, J=12.4,1 \mathrm{H}), 4.34(\mathrm{~d}, J=12.4 \mathrm{~Hz}, 1 \mathrm{H}), 4.14-4.20(\mathrm{~m}, 1 \mathrm{H}), 3.58$ (dd, $J=9.6$, $4.8 \mathrm{~Hz}, 1 \mathrm{H}), 3.39(\mathrm{dd}, J=9.6,6.4 \mathrm{~Hz}, 1 \mathrm{H}), 2.19(\mathrm{~m}, 2 \mathrm{H}), 1.62-1.66(\mathrm{~m}, 3 \mathrm{H}), 0.17(\mathrm{~s}, 3 \mathrm{H}), 0.19$ (s, $3 \mathrm{H}) .{ }^{13} \mathrm{C}$ NMR $\left(100 \mathrm{MHz}, \mathrm{C}_{6} \mathrm{D}_{6}\right) \delta 139.7,139.3,135.1,128.5,127.9,127.6,75.2,73.4$, 
71.0, 33.6, 20.5, -1.5, -1.6. IR (thin film) 2855, 1614, 1454, 1251, 1097, 967, 827, 781 $\mathrm{cm}^{-1}$.

\section{(士)-(3S,5R)-6-Benzyloxy-3,5-bis-triethylsilanyloxy-hexan-2-one, 46}

To a solution of the cyclic siloxane $\mathbf{4 4}(100 \mathrm{mg}, 0.381 \mathrm{mmol})$ in acetone $(1 \mathrm{~mL})$ was added DMDO (19.1 mL, $0.1 \mathrm{M}$ soln in acetone, $1.91 \mathrm{mmol})$ under $\mathrm{Ar}$ at $-78{ }^{\circ} \mathrm{C}$ via cannula. After stirring overnight at $-78^{\circ} \mathrm{C}$ the reaction was allowed to warm to $-20^{\circ} \mathrm{C}$ over $2 \mathrm{~h}$. At that temperature the reaction was quenched with dimethylsulfide $(355 \mathrm{mg}, 5.716 \mathrm{mmol})$. After warming to rt and drying over $\mathrm{MgSO}_{4}$ the mixture was concentrated under reduced pressure which afforded the crude epoxide $\mathbf{4 5}(157 \mathrm{mg}, 148 \%)$ as a colorless oil.

$\mathrm{R}_{\mathrm{f}}$ : 0.49 (4:1 pet. ether: EtOAc). ${ }^{1} \mathrm{H}$ NMR (400 MHz, $\left.\mathrm{C}_{6} \mathrm{D}_{6}\right) \delta$ 7.07-7.28 (m, 5H), $4.33(\mathrm{~s}, 2 \mathrm{H})$, $4.21(\mathrm{~m}, 1 \mathrm{H}), 3.38(\mathrm{dd}, J=9.6,4.8 \mathrm{~Hz}, 1 \mathrm{H}), 3.28(\mathrm{dd}, J=9.6,5.2 \mathrm{~Hz}, 1 \mathrm{H}), 2.82(\mathrm{~d}, J=3.6$ $\mathrm{Hz}, 1 \mathrm{H}), 1.96$ (ddd, $J=15.2,5.6,3.6 \mathrm{~Hz}, 1 \mathrm{H}), 1.76$ (dd, $J=15.2,11.2 \mathrm{~Hz} 1 \mathrm{H}), 1.04(\mathrm{~s}, 3 \mathrm{H})$, $0.25(\mathrm{~s}, 3 \mathrm{H}), 0.12(\mathrm{~s}, 3 \mathrm{H})$.

UHP (179 mg, $1.90 \mathrm{mmol}$ ) was added to a solution of the crude epoxide ( $157 \mathrm{mg}$, assume 0.381 mmol) in THF $(3.8 \mathrm{~mL})$ under Ar at $0{ }^{\circ} \mathrm{C}$. The reaction was allowed to warm to $\mathrm{rt}$ and treated with TBAF $(1.41 \mathrm{~mL}, 0.81 \mathrm{M}$ soln in THF, $1.143 \mathrm{mmol})$ dropwise via syringe pump over $4 \mathrm{~h}$. After stirring for $20 \mathrm{~h}$ at $\mathrm{rt}$ the reaction was stopped by diluting with EtOAc $(15 \mathrm{~mL})$ and aq. $\mathrm{Na}_{2} \mathrm{~S}_{2} \mathrm{O}_{3}(10 \mathrm{~mL}, 0.1 \mathrm{M}$ soln $)$. Extraction with EtOAc $(3 \times 10 \mathrm{~mL})$ and drying over $\mathrm{MgSO}_{4}$ afforded a crude oil (189 mg, $208 \%$ ) which was used directly in the next reaction.

The crude diol ( $189 \mathrm{mg}$, assume $0.381 \mathrm{mmol}$ ) and imidazole ( $431 \mathrm{mg}, 6.34 \mathrm{mmol}$ ) were solved in $\mathrm{CH}_{2} \mathrm{Cl}_{2}(7.9 \mathrm{~mL})$ under $\mathrm{N}_{2}$ at $0{ }^{\circ} \mathrm{C}$. Then $\mathrm{Et}_{3} \mathrm{SiCl}(660 \mathrm{~mL}, 3.966 \mathrm{mmol})$ was added via syringe at $0{ }^{\circ} \mathrm{C}$. After warming to rt, the mixture was stirred for $2 \mathrm{~h}$. The reaction was quenched with $\mathrm{H}_{2} \mathrm{O}(10 \mathrm{~mL})$ and diluted with diethyl ether $(30 \mathrm{~mL})$. The aq. layer was extracted with $\mathrm{Et}_{2} \mathrm{O}(3 \times 5 \mathrm{~mL})$, the organic extracts were washed with brine $(5 \mathrm{~mL})$ and dried over $\mathrm{MgSO}_{4}$. The resulting oil was purified on a silica gel column (30:1, then 20:1 pet ether: diethyl ether) which afforded the protected product $(138 \mathrm{mg})$ in $77 \%$ yield over 3 steps.

$\mathrm{R}_{\mathrm{f}}$ : $0.28\left(10: 1\right.$ pet. ether: $\left.\mathrm{Et}_{2} \mathrm{O}\right) .{ }^{1} \mathrm{H}$ NMR $\left(500 \mathrm{MHz}, \mathrm{CDCl}_{3}\right) \delta 7.26-7.35(\mathrm{~m}, 5 \mathrm{H}), 4.53(\mathrm{~d}, J$ $=12.1,1 \mathrm{H}), 4.49(\mathrm{~d}, J=12.1 \mathrm{~Hz}, 1 \mathrm{H}), 4.15(\mathrm{t}, J=6.5 \mathrm{~Hz}, 1 \mathrm{H}), 3.96-4.00(\mathrm{~m}, 1 \mathrm{H}), 3.38-3.43$ $(\mathrm{m}, 2 \mathrm{H}), 2.14(\mathrm{~s}, 3 \mathrm{H}), 1.76-1.95(\mathrm{~m}, 2 \mathrm{H}), 0.94(\mathrm{t}, \mathrm{J}=7.8,18 \mathrm{H}), 0.55-0.62(\mathrm{~m}, 12 \mathrm{H}) .{ }^{13} \mathrm{C}$ NMR $\left(125 \mathrm{MHz}, \mathrm{CDCl}_{3}\right) \delta 210.9,138.3,128.3,127.6,127.5,75.7,74.3,73.2,67.8,39.9,24.9,6.83$, 6.81, 6.74, 5.03, 4.87, 4.69. IR (thin film) 2955, 2877, 1717, 1456, 1415, 1352, 1239, 1100 , $1006,740 \mathrm{~cm}^{-1}$. Anal. Calc. for $\mathrm{C}_{25} \mathrm{H}_{46} \mathrm{O}_{4} \mathrm{Si}_{2}: \mathrm{C}, 64.32 ; \mathrm{H}, 9.93$. Found: C, 64.16; H, 10.08 .

\section{(+)-Spectaline, 67}

The azido-siloxane $77(7.1 \mathrm{mg}, 0.016 \mathrm{mmol})$ and solid urea-hydrogen peroxide adduct $(6 \mathrm{mg}$, $0.064 \mathrm{mmol})$ were taken up in DMF $(0.16 \mathrm{~mL})$ and treated at $0{ }^{\circ} \mathrm{C}$ with $\mathrm{TBAF}(63 \mathrm{~mL}, 0.063$ $\mathrm{mmol}, 1.0 \mathrm{M}$ in THF) dropwise via syringe pump over $4 \mathrm{~h}$. The mixture was then allowed to warm to rt and was stirred for $10 \mathrm{~h}$. At this time, TLC analysis indicated incomplete consumption of the starting vinylsilane, and so additional urea-hydrogen peroxide adduct $(6 \mathrm{mg}$, $0.064 \mathrm{mmol}$ ) was added, followed by additional TBAF (63 mL, $0.063 \mathrm{mmol}, 1.0 \mathrm{M}$ in THF) via syringe over $4 \mathrm{~h}$ as before. The mixture was then allowed to warm to $\mathrm{rt}$ and was stirred for $20 \mathrm{~h}$. The mixture was diluted with water $(5 \mathrm{~mL})$ and extracted with EtOAc $(3 \times 4 \mathrm{~mL})$. The organic layers were dried over $\mathrm{Na}_{2} \mathrm{SO}_{4}$ and concentrated in vacuo. The residue was purified on a silica gel column (eluent 7:1, then 4:1 pet. ether: EtOAc) to afford $5.2 \mathrm{mg}(84 \%)$ of the desired ketone 6.129. IR (thin film) 3456 (br, OH), 2923 (s), 2109 (s), 1713, 1463, 1377, 1256, $1060 \mathrm{~cm}^{-1}$. MS—CI (m/z): [M + Na] $]^{+}$calcd for $\mathrm{C}_{22} \mathrm{H}_{41} \mathrm{~N}_{3} \mathrm{O}_{4} \mathrm{Na}$ : 434.3 ; found: 434.3 . 
The keto-azide ( $2.4 \mathrm{mg}, 0.0058 \mathrm{mmol})$ was taken up in $\mathrm{EtOH}(0.5 \mathrm{~mL})$ and treated with $10 \%$ $\mathrm{Pd} / \mathrm{C}(1 \mathrm{mg})$. The mixture was placed under $60 \mathrm{psi}$ of $\mathrm{H}_{2}$ and stirred $24 \mathrm{~h}$. The mixture was filtered through celite, washing with additional $\mathrm{EtOH}(2 \mathrm{~mL})$. The filtrated was concentrated in vacuo and taken up in THF $(0.5 \mathrm{~mL})$. The solution was treated with aq. $\mathrm{HCl}(0.05 \mathrm{~mL}, 2.0$ $\mathrm{M}$ soln) and stirred for $24 \mathrm{~h}$ at $\mathrm{rt}$. The mixture was then quenched by addition of aq. $\mathrm{NaOH}$ $(0.5 \mathrm{~mL}, 1.0 \mathrm{M}$ soln $)$. The mixture was extracted with EtOAc $(2 \times 3 \mathrm{~mL})$, dried over $\mathrm{Na}_{2} \mathrm{SO}_{4}$, and concentrated in vacuo. The residue was purified on a column of basic alumina (eluent 100:1 $\mathrm{CHCl}_{3}$ : EtOH), affording $1.0 \mathrm{mg}(53 \%)$ of (+)-spectaline.

${ }^{1} \mathrm{H}$ NMR $\left(500 \mathrm{MHz}, \mathrm{CDCl}_{3}\right) \delta 3.54(\mathrm{~m}, 1 \mathrm{H}), 2.75(\mathrm{qd}, J=6.5,1.4 \mathrm{~Hz}, 1 \mathrm{H}), 2.52(\mathrm{~m}, 1 \mathrm{H}), 2.42$ (t, $J=7.5 \mathrm{~Hz}, 2 \mathrm{H}), 2.14(\mathrm{~s}, 3 \mathrm{H}), 1.90(\mathrm{~m}, 1 \mathrm{H}), 1.24-1.52(\mathrm{~m}, 27 \mathrm{H}), 1.09(\mathrm{~d}, J=6.6 \mathrm{~Hz}, 3 \mathrm{H})$. IR (thin film) $2926,2112,1251,1049,833,784 \mathrm{~cm}^{-1} \cdot[\alpha]_{\mathrm{D}}{ }^{27}+5.8\left(\mathrm{c} 0.1, \mathrm{CHCl}_{3}\right)$. Lit. ${ }^{16}$ $[\alpha]_{\mathrm{D}}+8.0\left(\mathrm{c} 0.16, \mathrm{CHCl}_{3}\right)$.

\section{(2S,3S)-2-Azido-9-(2-methyl-[1,3]dioxolan-2-yl)-5-octadecyn-3-ol, 76}

The terminal alkyne $73(150 \mathrm{mg}, 0.54 \mathrm{mmol})$ was taken up in THF $(2.0 \mathrm{~mL})$ and treated with butyllithium ( $0.34 \mathrm{~mL}, 0.54 \mathrm{mmol}, 1.6 \mathrm{M}$ in hexanes) at $-78{ }^{\circ} \mathrm{C}$ and stirred for $30 \mathrm{~min}$. The azido-epoxide 84 (137 $\mathrm{mg}$ of $34 \mathrm{wt} \%$ solution assuming $100 \%$ yield in previous step) was added to THF ( $2.0 \mathrm{~mL}$ ) over $4 \AA$ A molecular sieves (ca. $0.1 \mathrm{~g}$ ) and allowed to stand for $10 \mathrm{~min}$ before it was added to the reaction flask via cannula. $\mathrm{BF}_{3} \cdot \mathrm{OEt}_{2}(0.067 \mathrm{~mL}, 0.54 \mathrm{mmol})$ was then added, and after $15 \mathrm{~min}$, no epoxide was present by TLC analysis. Sat. aq. $\mathrm{NH}_{4} \mathrm{Cl}(3 \mathrm{~mL})$ and water $(10 \mathrm{~mL})$ were added, and the mixture extracted with ether $(3 \times 15 \mathrm{~mL})$. The organic layers were washed with brine $(5 \mathrm{~mL})$ and dried over $\mathrm{MgSO}_{4}$. Solvent removal in vacuo and purification on a silica gel column (eluent 100:10:1, then 85:15:1 pet. ether: EtOAc: methanol) gave $89 \mathrm{mg}$ (55\% from epoxy alcohol) of the alcohol as a colorless oil.

${ }^{1} \mathrm{H}$ NMR (500 MHz, $\left.\mathrm{CDCl}_{3}\right) \delta 3.90-3.97(\mathrm{~m}, 4 \mathrm{H}), 3.64(\mathrm{~m}, 1 \mathrm{H}), 3.58(\mathrm{dq}, J=5.5 \mathrm{~Hz}, 1 \mathrm{H})$, 2.43-2.45 (m, 2H), 2.14-2.18 (m, 3H), 1.61-1.64 (m, 2H), $1.48(\mathrm{~m}, 2 \mathrm{H}), 1.24-1.40(\mathrm{~m}, 20 \mathrm{H})$, $1.33(\mathrm{~d}, J=6.6 \mathrm{~Hz}, 3 \mathrm{H}), 1.31(\mathrm{~s}, 3 \mathrm{H}) .{ }^{13} \mathrm{C} \mathrm{NMR}\left(125 \mathrm{MHz}, \mathrm{CDCl}_{3}\right) \delta 110.2,83.7,74.8,73.2$, 64.5, 60.3, 39.2, 29.8, 29.57, 29.56, 29.54, 29.52, 29.48, 29.1, 28.85, 28.84, 24.6, 24.1, 23.7, 18.7, 15.7. IR (thin film) 3458 (br, OH), 2927 (s), $2100(\mathrm{~s}), 1377,1256,1062 \mathrm{~cm}^{-1} \cdot[\alpha]_{\mathrm{D}}{ }^{27}$ +40.4 (c 1.0, $\left.\mathrm{CH}_{2} \mathrm{Cl}_{2}\right)$. HRMS-EI (m/z): $\left[\mathrm{M}-\mathrm{CH}_{3}\right]^{+}$calcd for $\mathrm{C}_{21} \mathrm{H}_{36} \mathrm{~N}_{3} \mathrm{O}_{3}: 378.2757$; found: 378.2772. Anal. calc. for $\mathrm{C}_{22} \mathrm{H}_{39} \mathrm{~N}_{3} \mathrm{O}_{3}$ : C, 67.14; H, 9.99; N, 10.68. Found: $\mathrm{C}, 67.32$; H, $10.06 ; \mathrm{N}, 10.58$.

\section{(S)-6-((S)-1-Azido-ethyl)-2,2-dimethyl-3-[3-(2-methyl-[1,3]dioxolan-2-yl)-dodecanyl]-5,6- dihydro-2H-[1,2]oxasiline, 77}

A mixture of alkyne 76 (50 mg, $0.127 \mathrm{mmol}$ ) and 1,1,3,3-tetramethyldisilazane ( $85 \mathrm{mg}, 0.635$ mmol) was heated to $70{ }^{\circ} \mathrm{C}$ for $20 \mathrm{~h}$. The neat mixture was cooled to $\mathrm{rt}$ and concentrated in vacuo (ca. 1 torr) to remove volatile organic species. After $30 \mathrm{~min}$ under vacuum, the residue was taken up in $\mathrm{CH}_{2} \mathrm{Cl}_{2}(0.3 \mathrm{~mL})$ and treated with solid $1(3.2 \mathrm{mg}, 0.0064 \mathrm{mmol})$ at $0^{\circ} \mathrm{C}$. The solution was allowed to warm to rt over $2 \mathrm{~h}$, and was then filtered through florisil $(\mathrm{ca} .3 \mathrm{~cm})$, eluting with ether $(5 \mathrm{~mL})$, to afford $56 \mathrm{mg}(98 \%)$ of spectroscopically homogeneous cyclic vinylsilane without additional purification.

${ }^{1} \mathrm{H}$ NMR (400 MHz, $\left.\mathrm{C}_{6} \mathrm{D}_{6}\right) \delta 6.21(\mathrm{~m}, 1 \mathrm{H}), 3.59$ (ddd, $\left.J=11.0,4.6,2.6 \mathrm{~Hz}, 1 \mathrm{H}\right), 3.55(\mathrm{~s}, 4 \mathrm{H})$, $2.88(\mathrm{dq}, J=6.7,4.6 \mathrm{~Hz}, 1 \mathrm{H}), 2.22(\mathrm{~m}, 1 \mathrm{H}), 2.08(\mathrm{t}, J=7.5 \mathrm{~Hz}, 2 \mathrm{H}), 1.52-1.78(\mathrm{~m}, 6 \mathrm{H}), 1.34$ (s, 3H), 1.30-1.40 (m, 19H), $0.95(\mathrm{~d}, J=6.7 \mathrm{~Hz}, 3 \mathrm{H}), 0.26(\mathrm{~s}, 3 \mathrm{H}), 0.22(\mathrm{~s}, 3 \mathrm{H}) .{ }^{13} \mathrm{C}$ NMR $\left(125 \mathrm{MHz}, \mathrm{C}_{6} \mathrm{D}_{6}\right) \delta 139.9,138.8,110.2,75.3,64.6,61.0,39.8,35.8,32.5,30.4,30.11,30.07$, $30.0,29.9,24.6,24.1,15.3,-0.7,-0.8$. IR (thin film) 2926, 2112, 1251, 1049, 833, 784 $\mathrm{cm}^{-1} \cdot[\alpha]_{\mathrm{D}}{ }^{27}-313.4\left(\mathrm{c} 1.0, \mathrm{CH}_{2} \mathrm{Cl}_{2}\right)$. HRMS-EI (m/z): $\left[\mathrm{M}-\mathrm{CH}_{3}\right]^{+}$calcd for $\mathrm{C}_{23} \mathrm{H}_{42} \mathrm{~N}_{3} \mathrm{O}_{3} \mathrm{Si}$ : 436.3004; found: 436.3006 . 


\section{Supplementary Material}

Refer to Web version on PubMed Central for supplementary material.

\section{Acknowledgment}

The authors thank Thomas Jöge for important initial experiments. We acknowledge the National Science Foundation and the National Institutes of Health (GM13598) for their generous support of our programs Z.T.B. received support from an Althouse Family Stanford Graduate Fellowship. Mass spectra were provided by the Mass Spectrometry Facility, University of San Francisco, supported by the NIH Division of Research Resources.

\section{REFERENCES}

1. Alonso F, Beletskaya IP, Yus M. Chem. Rev 2004;104:3079-3159. [PubMed: 15186189] For a rare direct hydration to form aldehyde products:Tokunaga M, Wakatsuki Y. Angew. Chem., Int. Ed. Engl 1998;37:2867-2869.Tokunaga M, Suzuki T, Koga N, Fukushima T, Horiuchi A, Wakatsuki Y. J. Am. Chem. Soc 2001;123:11917-11924. [PubMed: 11724598]Tokunaga M, Wakatsuki Y. J. Synth. Org. Chem., Jpn 2000;58:587-596.Grotjahan DB, Incarvito CD, Rheingold AL. Angew. Chem., Int. Ed 2001;40:3884.

2. a) Tucker CE, Davidson J, Knochel P. J. Org. Chem 1992;57:3482-3485. b) Stork G, Bouch R. J. Am. Chem. Soc 1964;86:935-936.

3. Mizushima E, Sato K, Hayashi T, Tanaka M. Angew. Chem., Int. Ed. Engl 2002;41:4563-4565. [PubMed: 12458539]

4. Utimoto K. Pure Appl. Chem 1983;55:1845-1852.Trost BM, Horne DB, Woltering MJ. Angew. Chem., Int. Ed. Engl 2003;42:5987-5990. [PubMed: 14679550]

5. Trost BM, Ball ZT. J. Am. Chem. Soc 2003;125:30-31. [PubMed: 12515496]

6. Trost BM, Machacek MR, Ball ZT. Org. Lett 2003;5:1895-1898. [PubMed: 12762680]

7. Trost BM, Ball ZT, Jöge T. Angew. Chem., Int. Ed. Engl 2003;42:3415-3418. [PubMed: 12888974]

8. Chung LW, Wu Y-D, Trost BM, Ball ZT. J. Am. Chem. Soc 2003;125:11578-11582. [PubMed: 13129361]Trost BM, Ball ZT. J. Am. Chem. Soc 2001;123:12726-12727. [PubMed: 11741457]

9. Marshall JA, Yanik MM. Org. Lett 2000;2:2173-2175. [PubMed: 10891259]

10. Tamao K, Maeda K. Tetrahedron Lett 1986;27:65-68.

11. Tamao K, Maeda K, Tanaka T, Ito Y. Tetrahedron Lett 1988;29:6955-6956.

12. Jones GR, Landais Y. Tetrahedron 1996;52:7599-7662.

13. Noyori R, Ohkuma T. Pure Appl. Chem 1999;71:1493-1501.Noyori R, Ohkuma T. Angew. Chem., Int. Ed. Engl 2001;40:40-73. [PubMed: 11169691]

14. Anand NK, Carreira EM. J. Am. Chem. Soc 2001;123:9687-9688. [PubMed: 11572696]Boyall D, Frantz DE, Carreira EM. Org. Lett 2002;4:2605-2606. [PubMed: 12123387]Frantz DE, Fassler R, Carreira EM. J. Am. Chem. Soc 2000;122:1806-1807.

15. Fensterbank L, Malacria M, Sieburth SN. Synthesis 1997:813-854.Isobe M, Nishizawa R, Nishikawa T, Yoza K. Tetrahedron Lett 1999;40:6927-6932.Kahle K, Murphy PJ, Scott J, Tamagni R. J. Chem. Soc., Perkin Trans. 1 1997:997-999.Murphy PJ, Spencer JL, Procter G. Tetrahedron Lett 1990;31:1051-1054.

16. Denmark SE, Pan W. Org. Lett 2003;5:1119-1122. [PubMed: 12659588]

17. Fleming I, Henning R, Parker DC, Plaut HE, Sanderson PEJ. J. Chem. Soc., Perkin Trans. 1 1995:317337.

18. Miura K, Hondo T, Takahashi T, Hosomi A. Tetrahedron Lett 2000;41:2129-2132.

19. Miura K, Hondo T, Nakagawa T, Takahashi T, Hosomi A. Org. Lett 2000;2:385-388. [PubMed: 10814329]

20. Frater G, Guenther W, Mueller U. Helv. Chim. Acta 1989;72:1846-1851.

21. Hasan I, Kishi Y. Tetrahedron Lett 1980;21:4229. Also see Tomioka H, Suzuki T, Oshima K, Nozaki H. Tetrahedron Lett 1982;23:3387-3390.

22. Evans DA, Halstead DP, Allison BD. Tetrahedron Lett 1999;40:4461-4462. 
23. Shimizu M, Kawamoto M, Niwa Y. Chem. Commun 1999:1151-1152.

24. Mead KT. Tetrahedron Lett 1987;28:1019-1022.

25. Kalkofen R, Brandau S, Wibbeling B, Hoppe D. Angew. Chem., Int. Ed. Engl 2004;43:6667-6669. [PubMed: 15593155]Oezluegedik M, Kristensen J, Reuber J, Froehlich R, Hoppe D. Synthesis 2004:2303-2316.Seppi M, Kalkofen R, Reupohl J, Froehlich R, Hoppe D. Angew. Chem., Int. Ed. Engl 2004;43:1423-1427. [PubMed: 15368424]

26. Tamao K, Ishida N, Tanaka T, Kumada M. Organometallics 1983;2:1694-1696.

27. Murray RW, Jeyaraman R. J. Org. Chem 1985;50:2847-2853.

28. Stachel SJ, Danishefsky SJ. Tetrahedron Lett 2001;42:6785-6787.

29. Trost BM, Ball ZT. Unpublished results

30. Rychnovsky SD, Rogers B, Yang G. J. Org. Chem 1993;58:3511-3515.

31. Marshall JA, Bourbeau MP. Org. Lett 2002;4:3931-3934. [PubMed: 12599495]

32. We believe the second, unstable product to be the anomer of 65 , existing as the alternative chair conformation relieving 1,3-diaxial interactions. We have not been able to sufficiently characterize this compound.

33. Fodor G, Fumeaux JP, Sankaran V. Synthesis 1972:464.Cook GR, Beholz LG, Stille JR. J. Org. Chem 1994;59:3575-3584.

34. Momose T, Toyooka N, Jin M. J. Chem. Soc., Perkin Trans. 1 1997:2005-2013.Makabe H, Kong LK, Hirota M. Org. Lett 2003;5:27-29. [PubMed: 12509882]Cook GR, Beholz LG, Stille JR. Tetrahedron Lett 1994;35:1669-1672.Lee YS, Shin YH, Kim YH, Lee KY, Oh CY, Pyun SJ, Park HJ, Jeong JH, Ham WH. Tetrahedron: Asymmetry 2003;14:87-93.Singh R, Ghosh SK. Tetrahedron Lett 2002;43:7711-7715.Wang Q, Sasaki NA. J. Org. Chem 2004;69:4767-4773. [PubMed: 15230600]Pahl A, Wartchow R, Meyer HH. Tetrahedron Lett 1998;39:2095-2096.

35. Kang, MC. Thesis. Corvallis: Dept. of Chem.; Oregon St. Univ.; 1983. Chandrasekhar S, Reddy CR. Tetrahedron: Asymmetry 2002;13:261-268.

36. Bessodes M, Saiah M, Antonakis K. J. Org. Chem 1992;57:4441-4444.

37. Panek JS, Zhang J. J. Org. Chem 1993;58:294-296.

38. Kajimoto T, Liu KKC, Pederson RL, Zhong Z, Ichikawa Y, Porco JA Jr, Wong CH. J. Am. Chem. Soc 1991;113:6187-6196.Takaoka Y, Kajimoto T, Wong CH. J. Org. Chem 1993;58:4809-4812. 


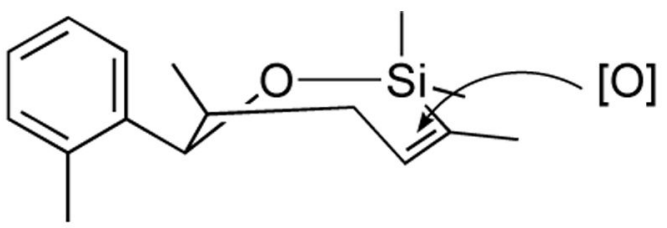

66

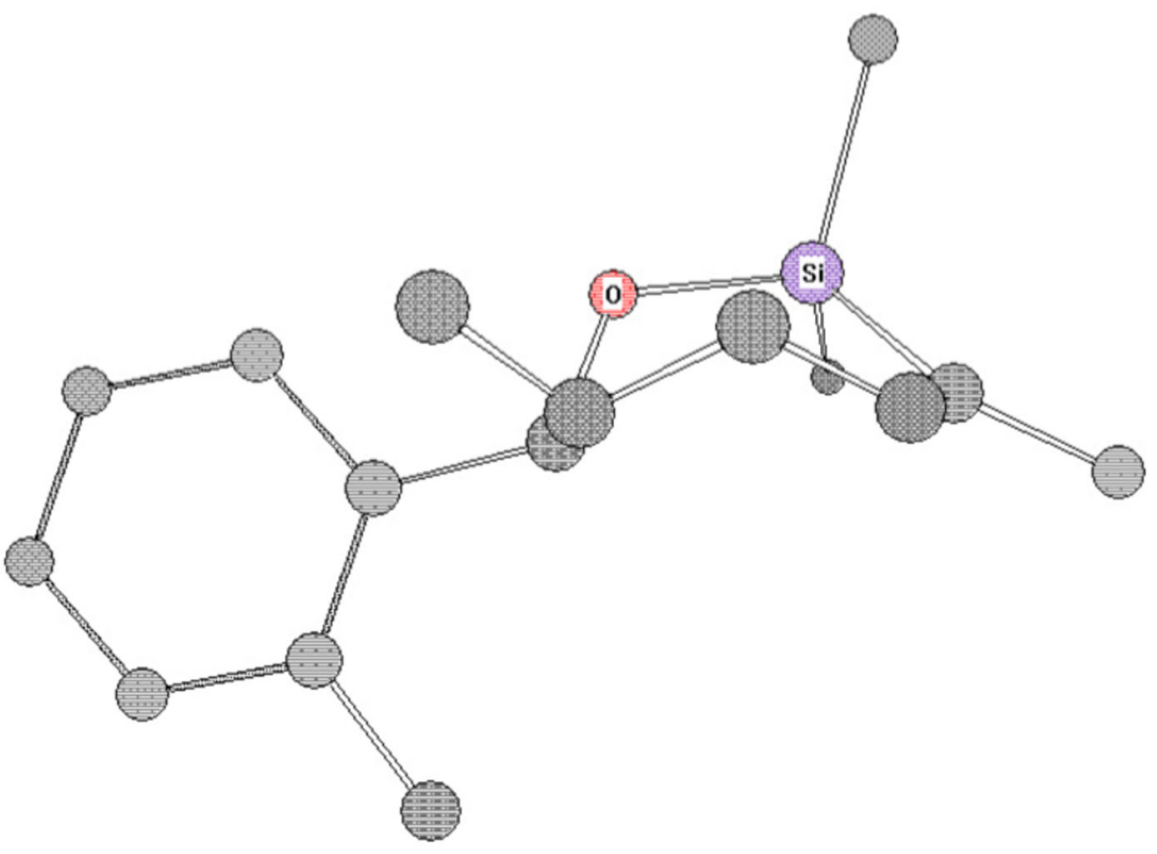

Figure 1.

Conformational analysis of a bishomopropargylic alcohol system. 
<smiles>[R]C(=O)CC</smiles>
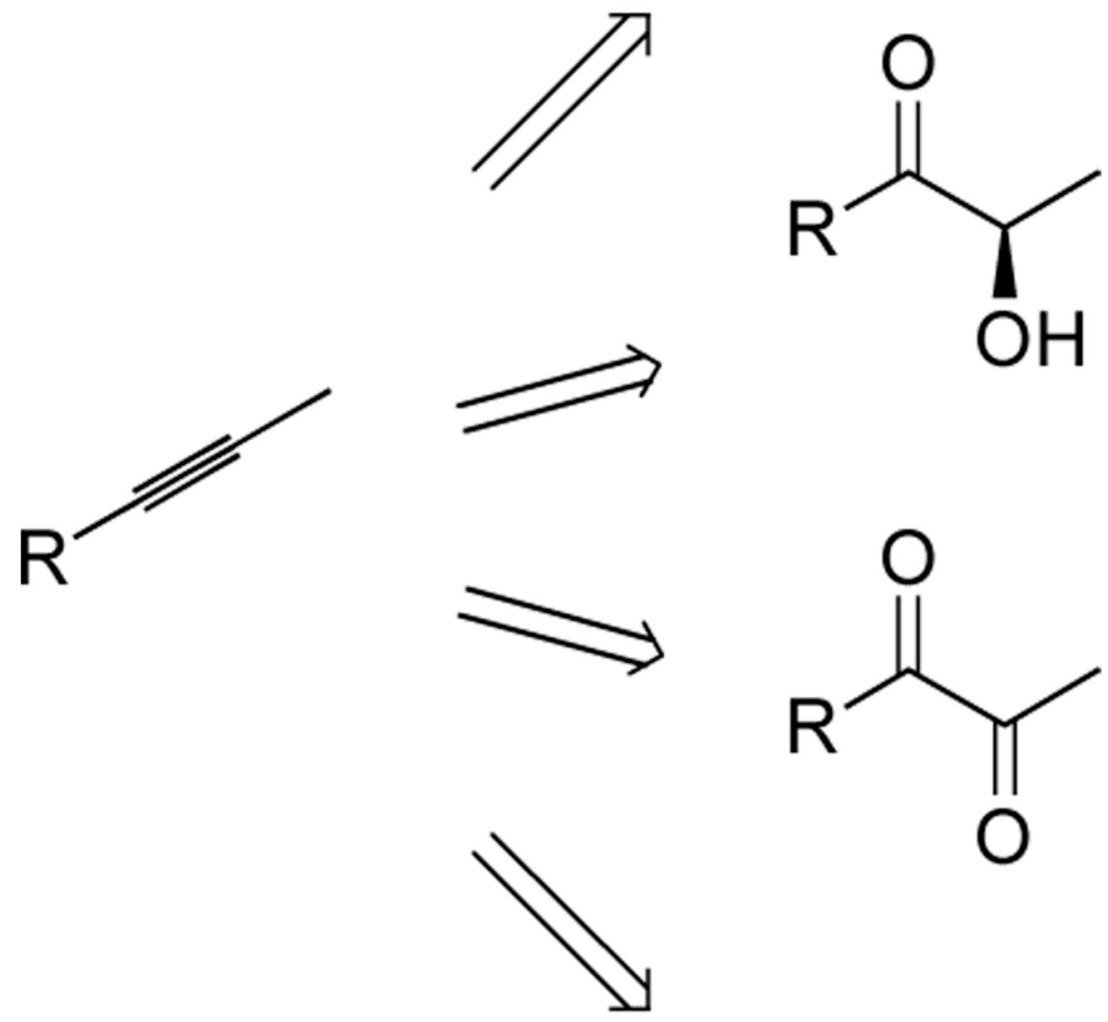

O

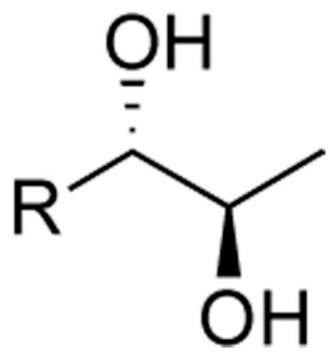

Scheme 1.

Alkyne building blocks for highly oxygenated targets. 

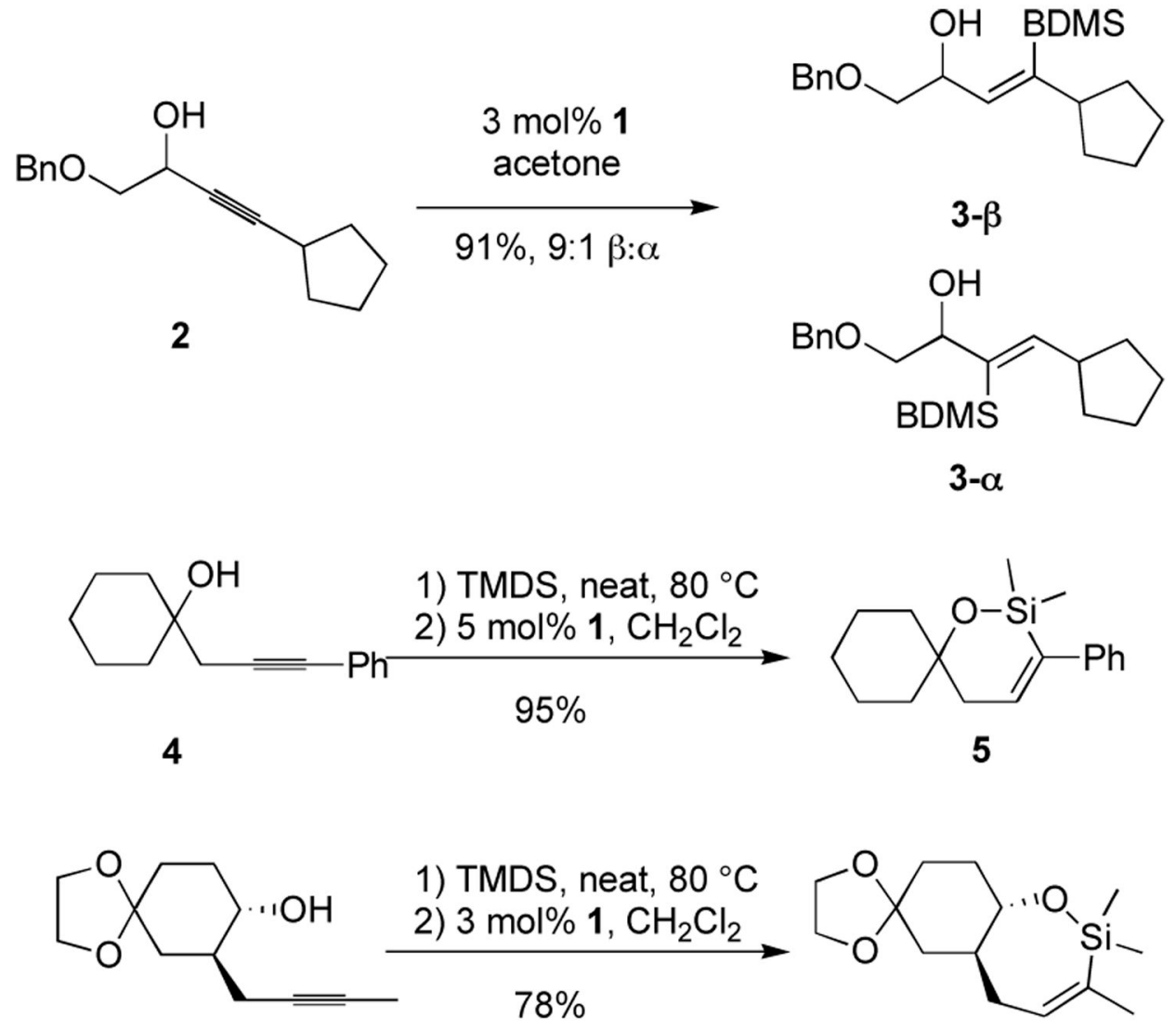

6

Scheme 2.

Hydrosilylation directed by hydroxy groups. 


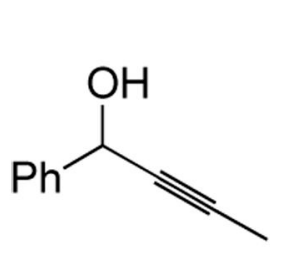

8

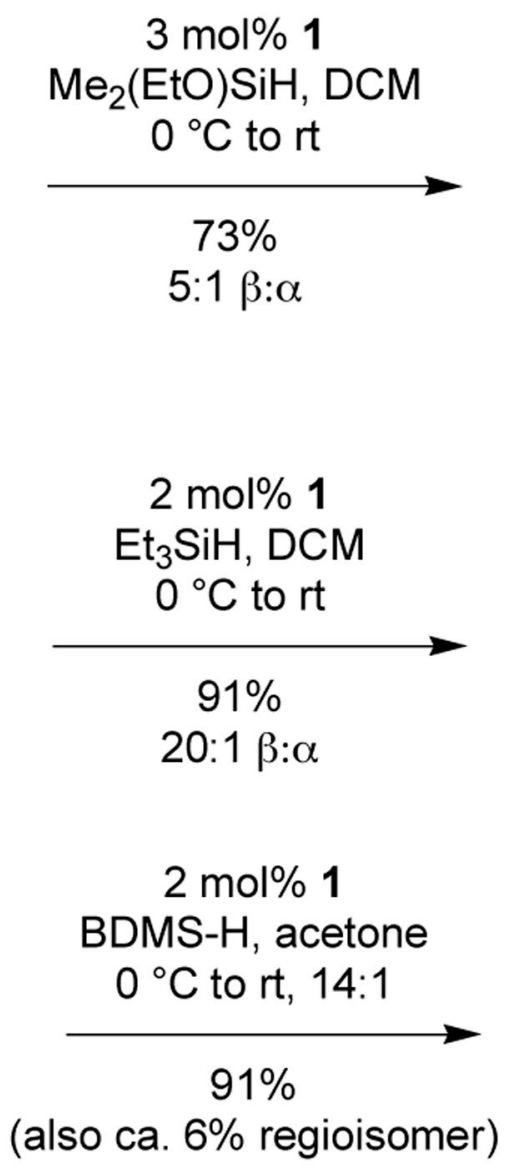

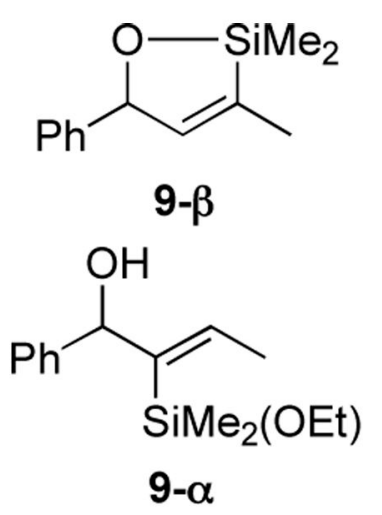<smiles>C/C(=C/C(O)c1ccccc1)[Te]=S</smiles>

10

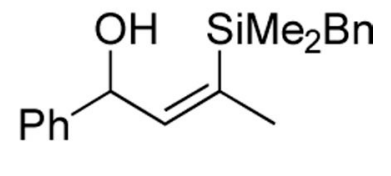

11

Scheme 3.

Hydrosilylation of propargylic alcohols. 
<smiles>CC#CC(O)c1ccccc1</smiles>

14
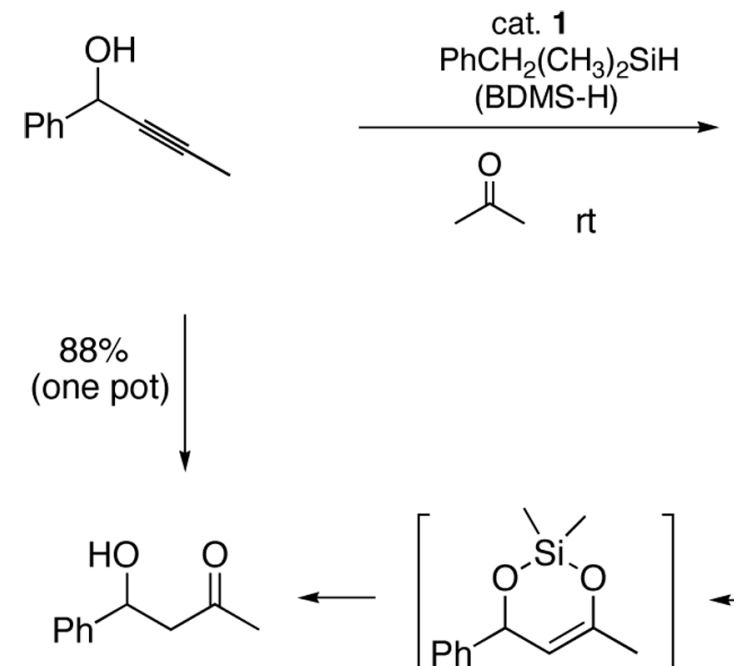

$\mathrm{PhCH}_{2}\left(\mathrm{CH}_{3}\right)_{2} \mathrm{SiH}$

rt

Scheme 4.

An Aldol Surrogate

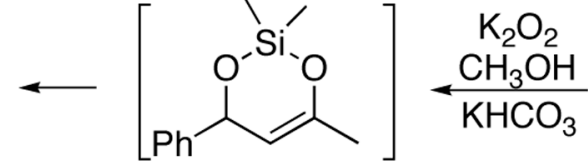

13<smiles></smiles>

TBAF<smiles>CC1=CC(c2ccccc2)O[SiH]1C</smiles>

12 


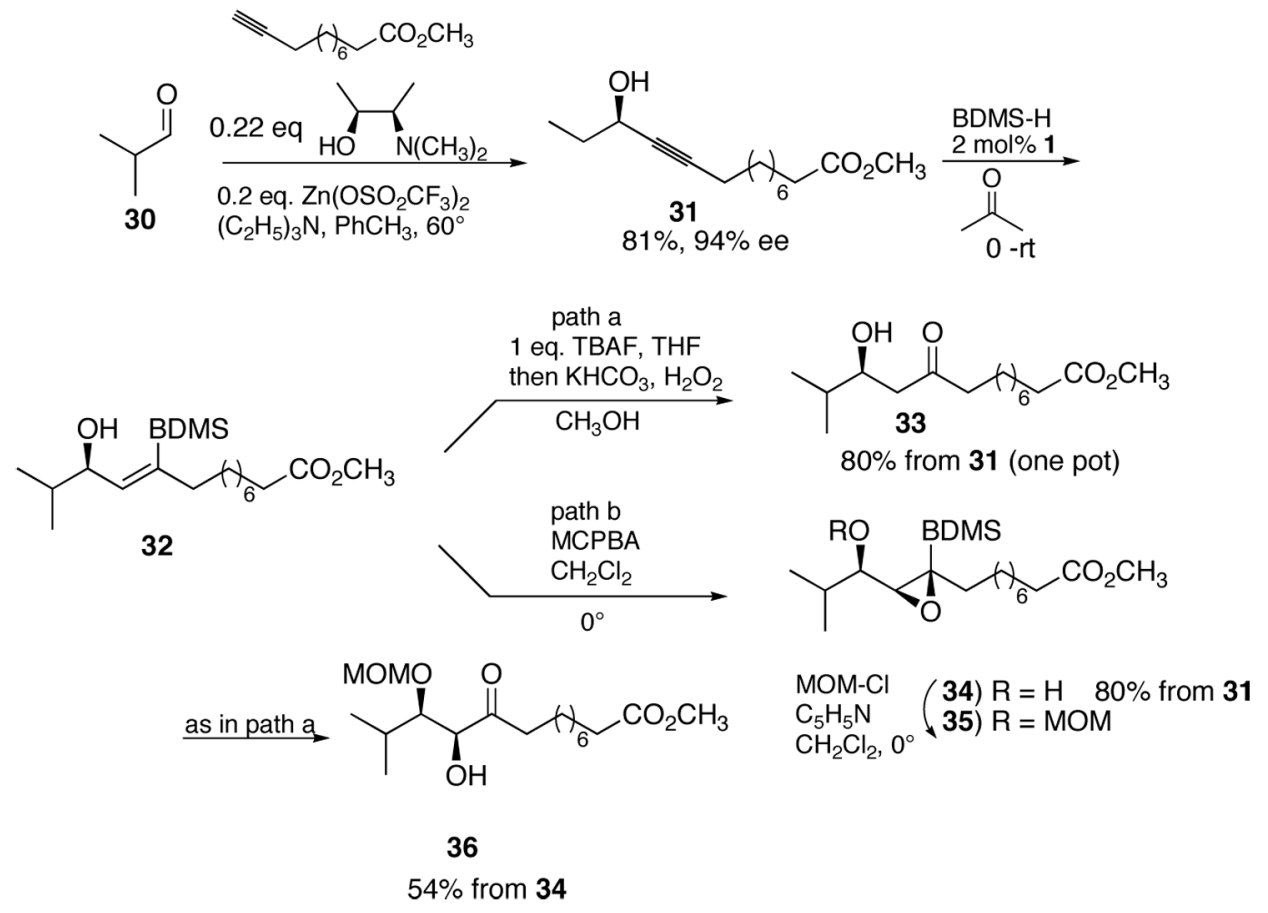

Scheme 5 .

Asymmetric Aldol and Oxidative Aldol Surrogate 
<smiles>[R]C(=O)CC([R3])[C@@H]([R])O</smiles>

or

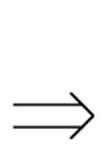<smiles>[R]C(=O)C(O)C([R3])C([R])O</smiles><smiles>[R]C(=O)C[IH]CC([R])O</smiles><smiles>[R]C(=O)[C@@H](O)[C@@H]([R3])C[C@@H]([R])O</smiles><smiles>C=CCCCC</smiles><smiles>[R]C1CCCC1</smiles><smiles>[R]C1=CC([R3])C([R])O[Si](C)(C)C1[R]</smiles><smiles>[R]C#CC[C]([R3])[C@@H]([R])O</smiles><smiles>[R]C#CC([R3])C([R])O</smiles>

\section{Scheme 6.}

Vinylsilane analysis of $\gamma$ - and $\delta$-hydroxy systems. 


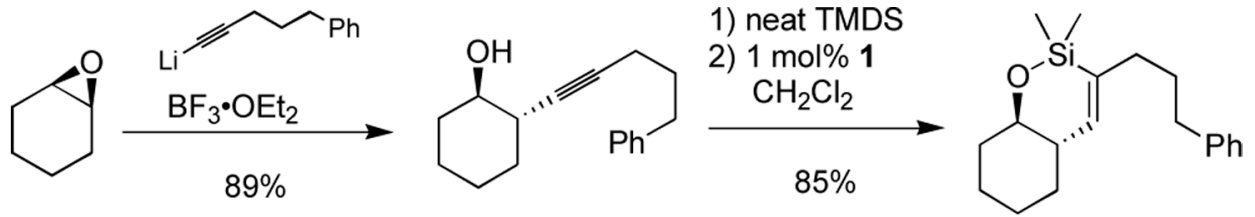

37

38

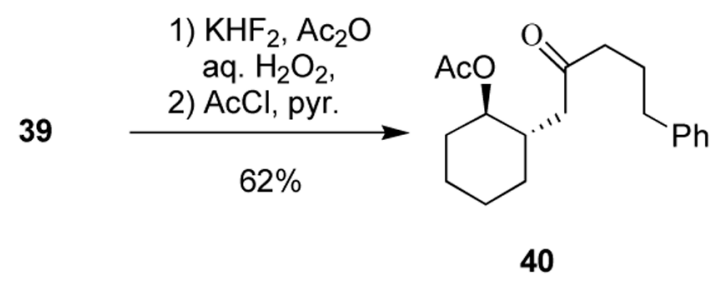

39

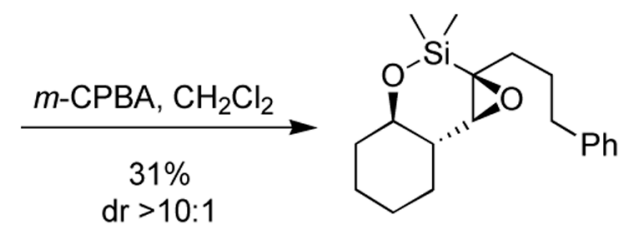

41

Scheme 7.

A methyl ketone enolate equivalent for homoaldol processes. 


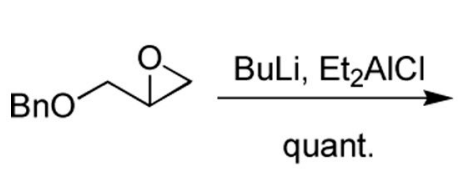

42

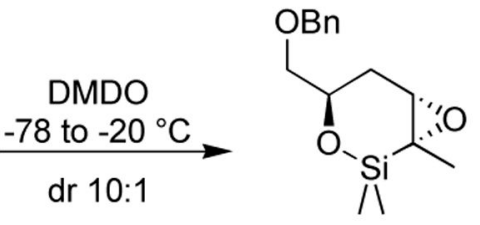

45

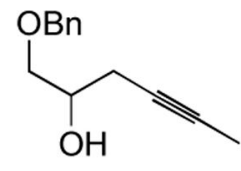

43 i) TMDS, $50^{\circ} \mathrm{C}$

ii) $2 \mathrm{~mol} \% 1$ $\mathrm{CH}_{2} \mathrm{Cl}_{2}$

$90 \%$

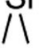<smiles>CC1=CCC(COCc2ccccc2)O[Si]1(C)C</smiles>

44
1) UHP, THF, then TBAF via syringe pump 2) $\mathrm{Et}_{3} \mathrm{SiCl}$, imidazole $77 \%$ (3 steps)

Scheme 8.

Synthesis of $\alpha, \gamma$-dihydroxy ketone by a cyclic silyl epoxide method. 

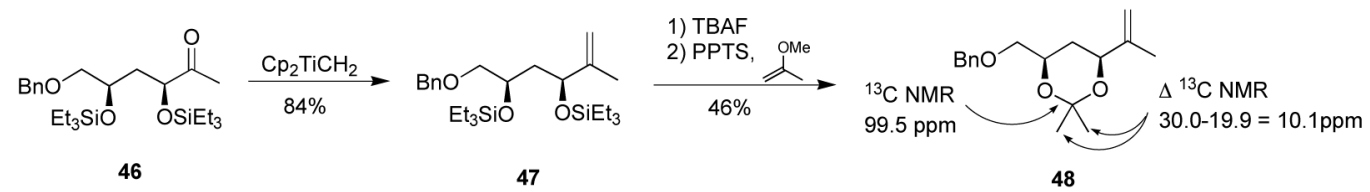

Scheme 9.

Determination of relative stereochemistry. 

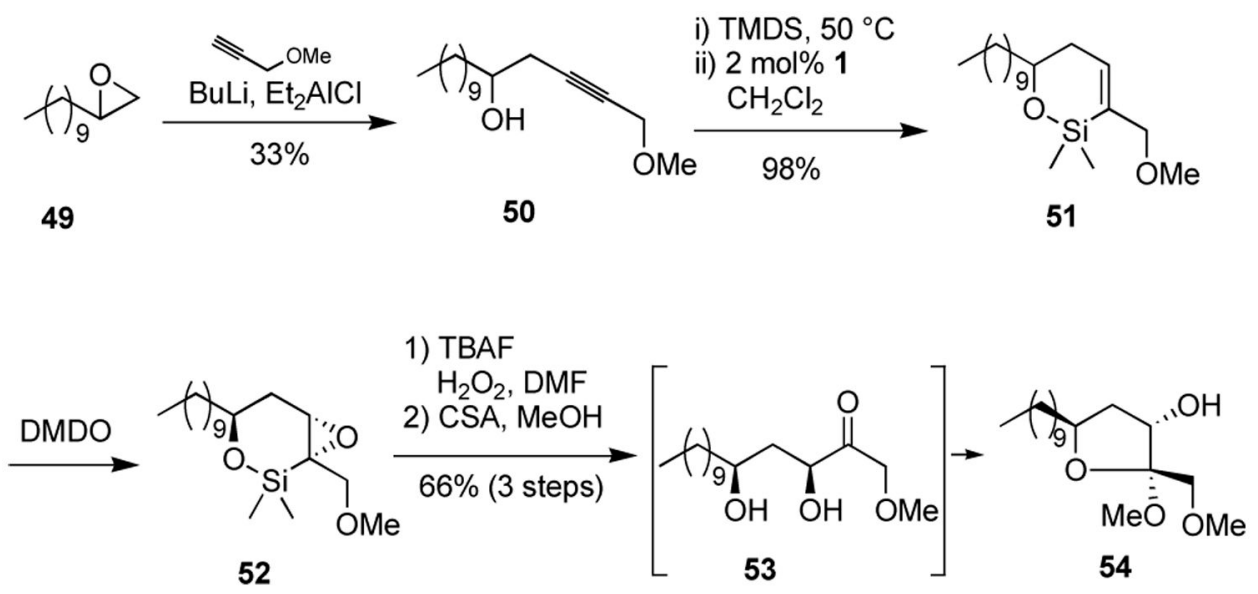

Scheme 10.

Synthesis of $\alpha, \gamma$-dihydroxy ketone with selective methyl ketal formation for diol differentiation. 


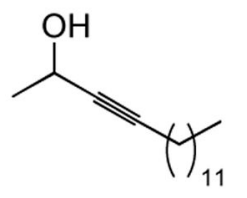

55<smiles>CC(C)[C@H]1O[Si](C)(C)C(C2CC2(C)C)=C[C@H]1C</smiles>

57

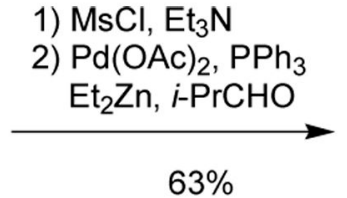

$63 \%$

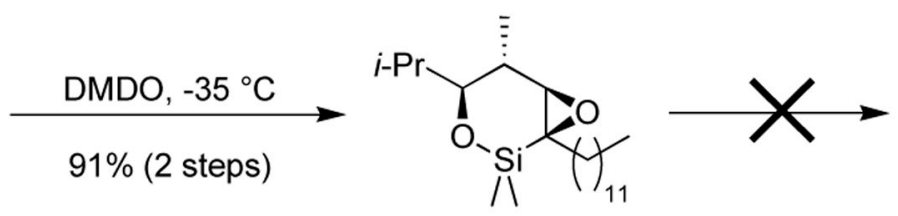

58

Scheme 11.

Oxidation problems for a homopropargylic alcohol with additional steric hindrance. 


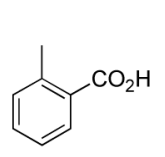

59

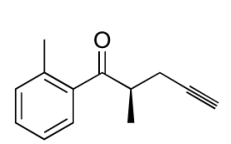

1) $\mathrm{Et}_{3} \mathrm{SiH}$, cat. $\mathrm{B}\left(\mathrm{C}_{6} \mathrm{~F}_{5}\right)_{3}, 68 \%$

2) BuLi, Mel

3) TBAF, $45 \%$ (2 steps)

$5: 1 d r$

60

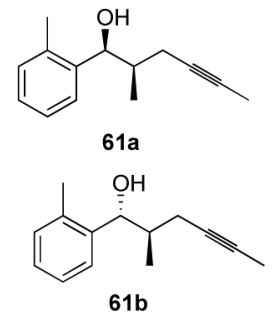

stereochemistry not determined

1) TBAF, $\mathrm{H}_{2} \mathrm{O}_{2}$, DMF 2) $\mathrm{Et}_{3} \mathrm{Si}-\mathrm{Cl}$, imid. $76 \%$ (3 steps) $\longrightarrow$

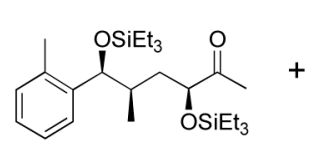

$63 a$

$5: 1$

$63 b$

Scheme 12.

Utilization of bishomopropargylic alcohol substrates. 


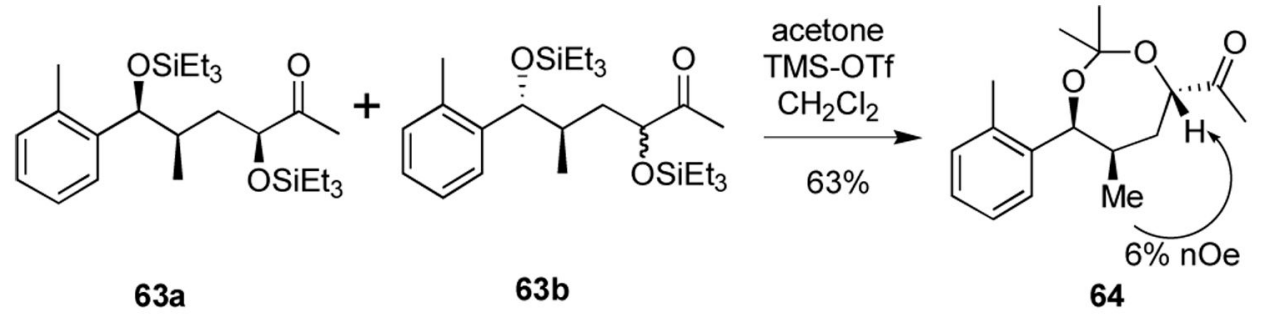

$63 a$

$63 b$ 64

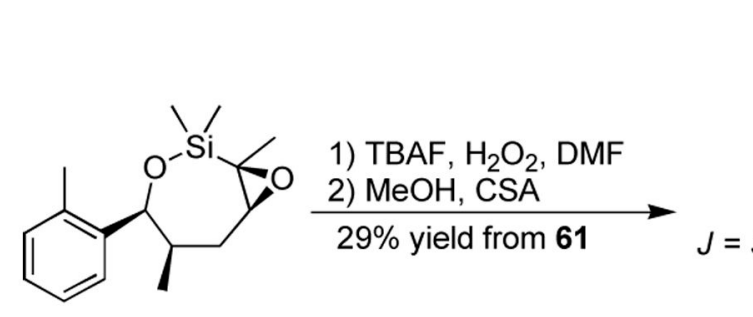

$62 a(+$ minor isomer) ddd

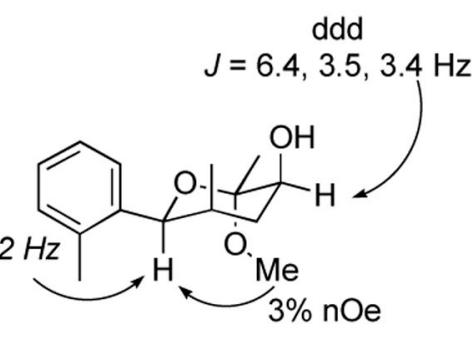

65

Scheme 13.

Determination of stereochemistry. 
<smiles>CC(=O)C1CCC1C[C@H]1CC[C@@H](O)[C@@H](C)N1</smiles>

67

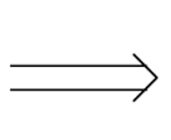<smiles>CC(=O)CC1CCC(CC(=O)CC[C@@H](O)[C@@H](C)N)C1</smiles>

68

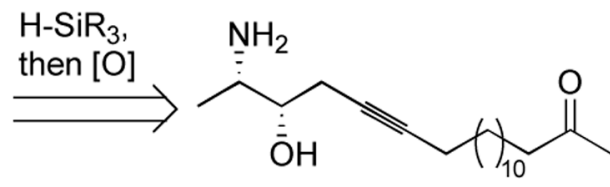

69<smiles>C=CCCCCC#CCCCCCCCC(C)=O</smiles>

70
71

Scheme 14.

Retrosynthetic analysis of (+)-spectaline. 

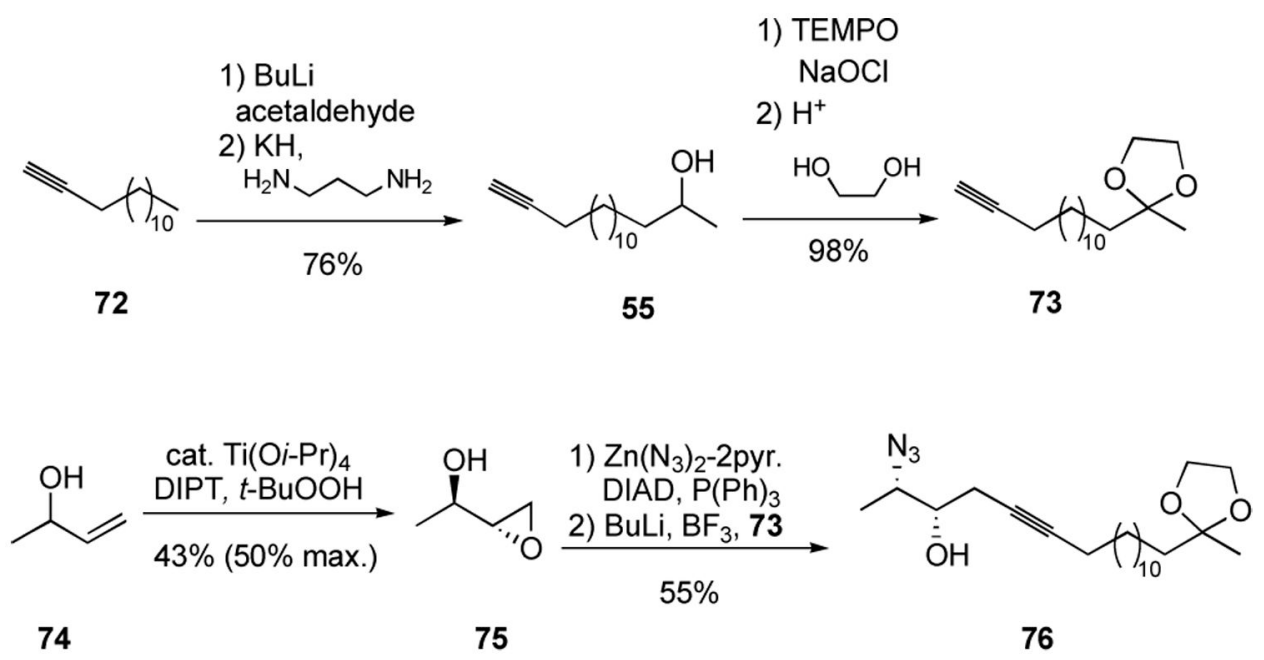

Scheme 15.

Synthesis of the requisite homopropargylic alcohol. 


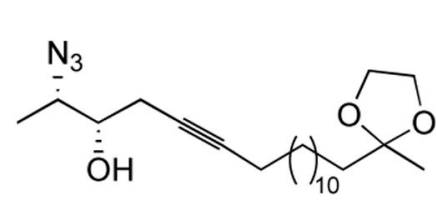

76

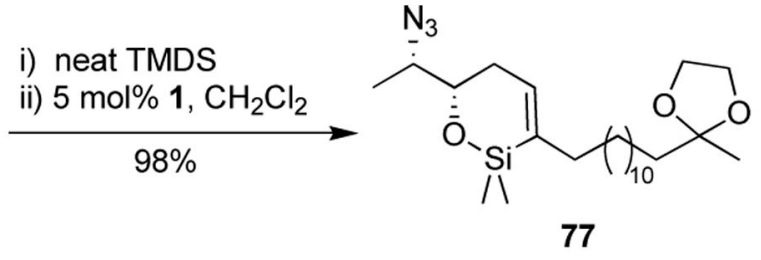

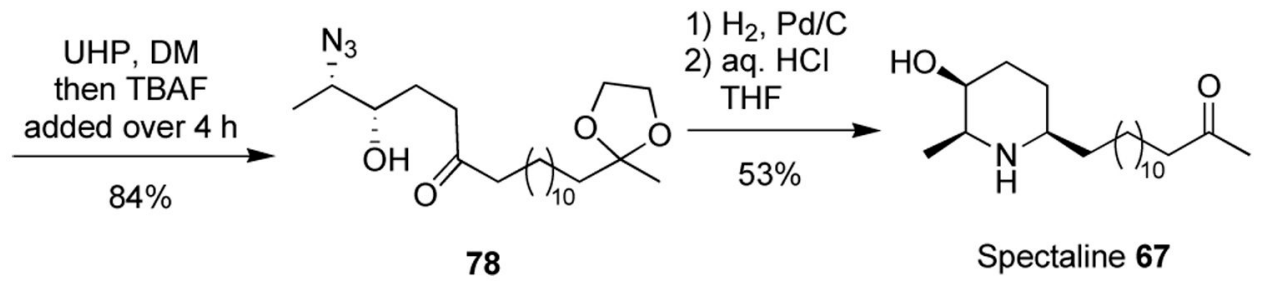

Scheme 16.

Completion of the synthesis of spectaline. 
<smiles>[R]C(=O)C([X])C([R])O</smiles><smiles>CC=O</smiles><smiles>[R]C#C</smiles><smiles>[X]O</smiles>

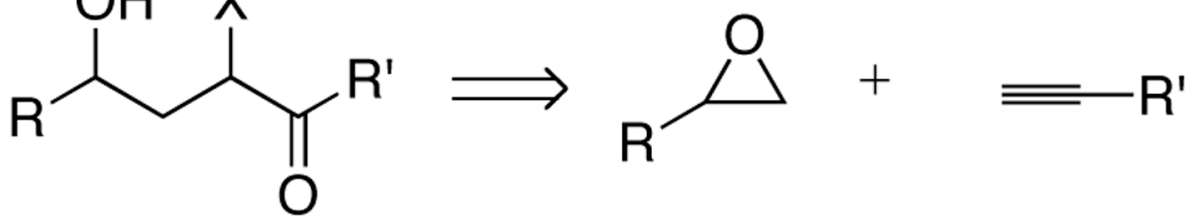<smiles>[R]C(=O)C([X])CCC([R])O</smiles><smiles>CC1CCO1</smiles>

$+$<smiles>[B]C#C</smiles>

Scheme 17.

Strategic Approach to Hydroxyketones 

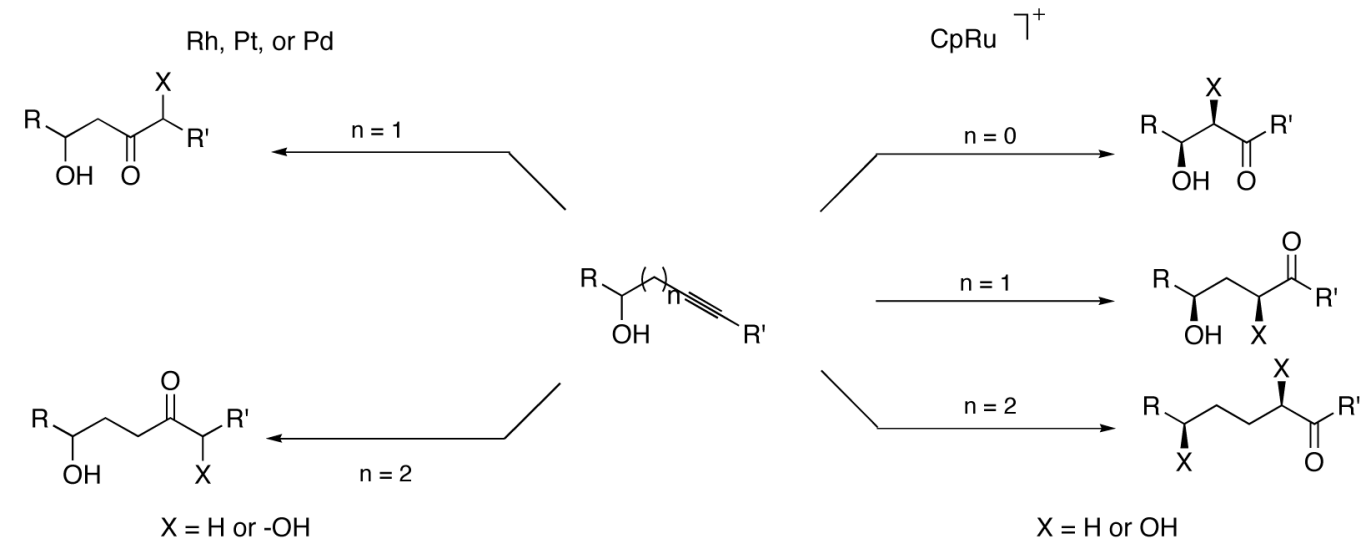

Scheme 18.

Complementary Behavior Based Upon Hydrosilylation Catalyst 